\title{
New Species of Onthophagus Latreille (Coleoptera : Scarabaeidae) from Australia
}

\author{
R. I. Storey ${ }^{\mathrm{A}}$ and T. A. Weir ${ }^{\mathrm{B}}$ \\ A Department of Primary Industries, P.O. Box 1054, Mareeba, Qld 4880, Australia.

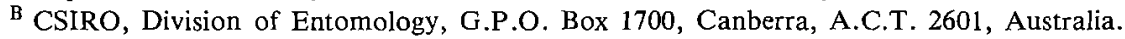

\begin{abstract}
Twenty new Australian species of the scarabaeine genus Onthophagus Latreille are described: $O$. arkoola, $O$. beelarong, $O$. bindaree, O. binyana, $O$. bundara, $O$. cooloola, $O$. dinjerra, O. godarra, O. gurburra, O. kakadu, O. mije, O. mongana, $O$. pinaroo, O. trawalla, O. weringerong, $O$. williamsi, $O$. worooa, $O$. yackatoon, $O$. yaran, $O$. yourula. Notes and scanning electron micrographs are given to assist in the separation of each from previously described Australian species. Distribution maps are provided for each species.
\end{abstract}

\section{Introduction}

Matthews (1972) revised the Australian species of the large cosmopolitan scarabaeine genus Onthophagus Latreille, recognising 165 species in 24 species groups. Storey (1977) described six new species in Matthews' rubescens group bringing the total to 171. This paper describes a further 20 species in 13 of Matthews' groups bringing the total to 191 Australian species. Matthews' (1972) difficult quadripustulatus species group is not included in the present work, though several new species and synonymy problems are known to occur. Further undescribed species are also present in Australian collections but as these are represented by insufficient material, it was felt that the need for the current paper warranted leaving the others until their status was more certain.

Matthews' (1972) species groupings are maintained and species are discussed in the order used in that work. Notes and scanning electron micrographs are given for each new species to aid in separation from previously described species. Most new species names are based on Aboriginal words and are to be treated as nouns in apposition, with Reed and Reed (1965) as the source.

The new species have been put into Matthews (1972) groups as follows:

glabratus group: kakadu, sp. nov.

conspicuus group: worooa, sp. nov., mongana, sp. nov.

capella group: cooloola, sp. nov., williamsi, sp. nov.

dunningi group: pinaroo, sp. nov.

australis group: yourula, sp. nov., weringerong, sp. nov.

auritus group: beelarong, sp., nov., gurburra, sp. nov.

adelaidae group: dinjerra, sp. nov., godarra, sp. nov.

perpilosus group: arkoola, sp. nov.

mutatus group: yaran, sp. nov. 
posticus group: yackatoon, sp. nov.

rubescens group: bundara, sp. nov., bindaree, sp. nov., trawalla, sp. nov.

bicarinaticeps group: mije, sp. nov.

ungrouped species: binyana, $\mathrm{sp}$ nov.

\section{Abbreviations}

The following abbreviations are used for the names of institutions and collections where specimens examined in this study are held or are to be lodged:

ANIC Australian National Insect Collection, CSIRO, Canberra, A.C.T.

ANIC (MMUS) Australian National Insect Collection, CSIRO (on permanent loan from the

Macleay Museum, University of Sydney), Canberra, A.C.T.

$\begin{aligned} \text { AWHC } & \text { A. Walford-Huggins Collection, Yeppoon, Qld } \\ \text { BMNH } & \text { British Museum (Natural History), London, U.K. } \\ \text { GWC } & \text { G. Williams Collection, Lansdowne, N.S.W. } \\ \text { HFHC } & \text { H. F. Howden Collection, Ottawa, Canada } \\ \text { NSWDA } & \text { New South Wales Department of Agriculture, Sydney, N.S.W. } \\ \text { PGAC } & \text { P. G. Allsopp Collection, Bundaberg, Qld } \\ \text { QDPI } & \text { Entomology Branch, Department of Primary Industries, Brisbane, Qld } \\ \text { QDPIM } & \text { Entomology Branch, Department of Primary Industries, Mareeba, Qld } \\ \text { QM } & \text { Queensland Museum, Brisbane, Qld } \\ \text { QUE } & \text { Department of Entomology, University of Queensland, Brisbane, Qld } \\ \text { SAMA } & \text { South Australian Museum, Adelaide, S.A. } \\ \text { WAM } & \text { Western Australian Museum, Perth, W.A. }\end{aligned}$

Genus Onthophagus Latreille, 1802

glabratus group

Onthophagus kakadu, sp. nov.

(Figs 6-8)

\section{Material Examined}

Holotype. $\sigma^{\circ}$, Northern Territory: $12^{\circ} 52^{\prime} \mathrm{S} ., 132^{\circ} 50^{\prime} \mathrm{E}$., Koongarra, $15 \mathrm{~km}$ E. of Mt Cahill, $27-$ 28.xi.1974, R. I. Storey, in QM, T10 891.

Paratypes. (14), Northern Territory: 10, 13Q, same data as holotype. Paratypes in: ANIC, QDPIM, QUE.

\section{Description}

Black, antennal clubs fulvous. Total length $7 \cdot 3-9 \cdot 0 \mathrm{~mm}$.

\section{Male}

Head. Clypeal margin medially bidentate, excised in a broadly rounded ' $\mathrm{V}$ ' between teeth, rest of margin broadly curved to genal angles, which are subangulate, rounded. Frontal section of clypeal suture effaced, rest strong. Frons unsculptured. Eyes dorsally about 16 facet rows in width, separated by about seven eye widths, canthus complete. Feebly rugose on front half of clypeus, frons feebly shagreened, punctures sparse, minute, smooth, nitid, glabrous. Labium excised about halfway to base.

Pronotum. Moderately convex, unsculptured. Anterior angles subquadrate, feebly turned out. Hind edge unmargined. Surface very smooth, nitid, except anterior angles which are feebly shagreened, punctures minute, glabrous.

Elytra. Intervals feebly convex, nitid, impunctate. Striae fine, geminate. Glabrous or with a few short setae below humeri and along apical edges.

Legs. Fore tibiae slightly compressed. Claws moderately prehensile.

Abdomen. Pygidium feebly convex, shagreened with scattered punctures, those on sides with short recumberit setae. Aedeagus as in Fig. 7. 


\section{Female}

Clypeus rugose, more acutely bidentate. Clypeal suture variable, complete in some, effaced in central portion in others, completely effaced in one specimen. Fore tibiae normal. Otherwise like male.

\section{Distribution (Fig. 1)}

Known only from the type locality; trapped with human excrement bait.
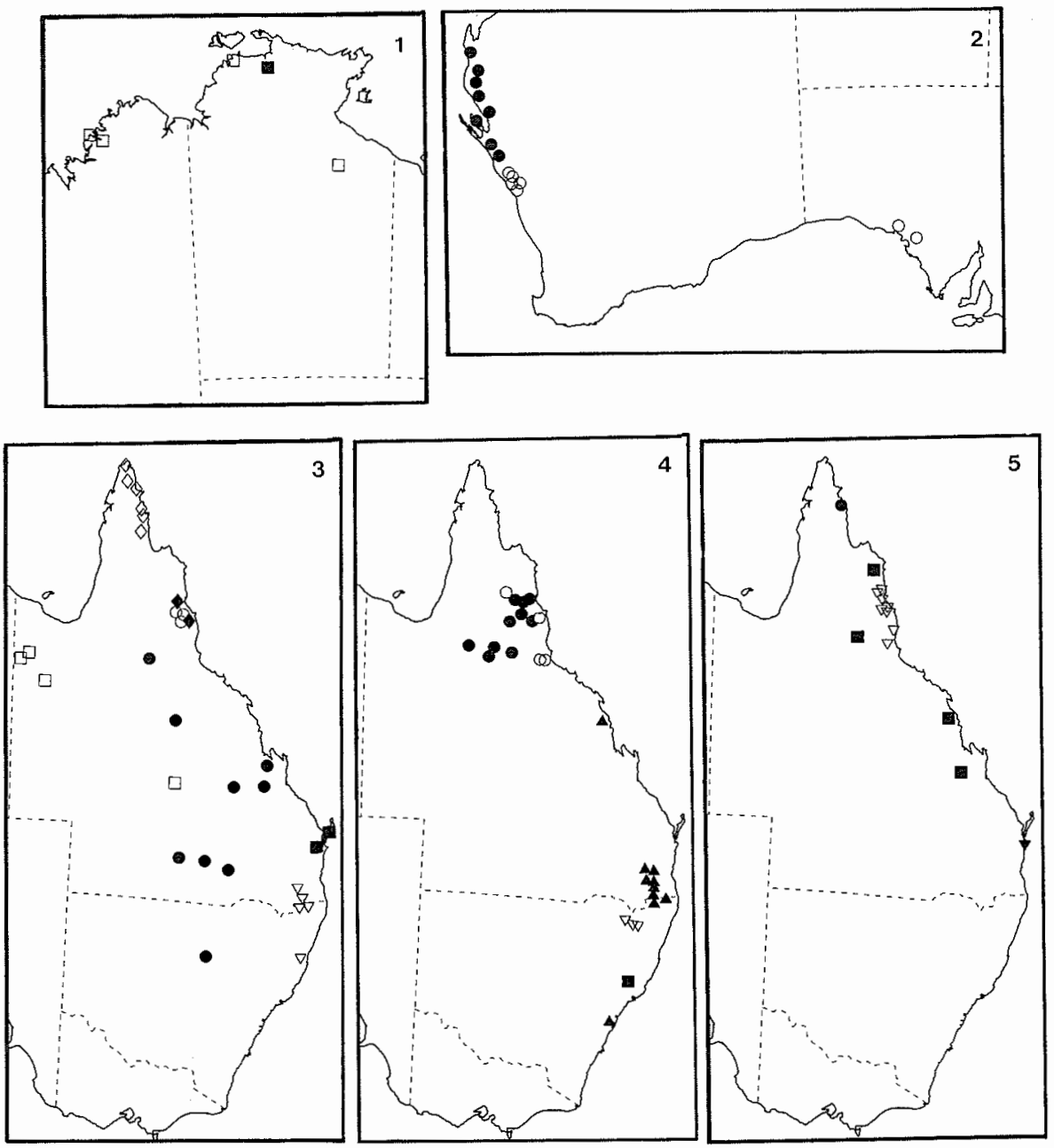

Fig. 1. Distribution of: $O$. bindaree, sp. nov. ( $\square)$; O. kakadu, sp. nov. (四).

Fig. 2. Distribution of: $O$. dinjerra, sp. nov. (O); O. godarra, sp. nov. (๑).

Fig. 3. Distribution of: $O$. arkoola, sp. nov. ( $\square)$; O. beelarong, sp. nov. (1); O. bundara, sp. nov. $(\diamond)$; $O$. gurburra, sp. nov. $(\diamond) ; O$. mongana, sp. nov. $(O)$; $O$. weringerong, sp. nov. $(\nabla)$; O. worooa, sp. nov. (๑).

Fig. 4. Distribution of: $O$. pinaroo, sp. nov. (O); O. williamsi, sp. nov. (四); O. yackatoon, sp. nov. $(\nabla)$; O. yaran, sp. nov. (๑); O. yourula, sp. nov. (\).

Fig. 5. Distribution of: $O$. binyana, sp. nov. $(\nabla) ; O$. cooloola, sp. nov. $(\nabla)$; O. mije, sp. nov. (曾); O. trawalla, sp. nov. ().

\section{Comments}

This species is closely related to $O$. murchisoni Blackburn, but differs in the very nitid dorsal surface, moderately prehensile claws, slightly larger eyes and more quadrate pronotal 
apices. It keys easily to O. murchisoni/O. carmodensis Blackburn in Matthews' (1972) key to the glabratus group, where it can be distinguished from both these species by the very nitid dorsal surface.

\section{conspicuus group}

Onthophagus worooa, sp. nov.

(Figs 9-11)

\section{Material Examined}

Holotype. Ơ, Queensland: 27 km E. of Forsayth, 20-21.xi.1976, R. I. Storey, in QM, T10 896.

Paratypes. (94), Queensland: $100^{\circ}, 12 \%$, same data as holotype, 160, 16\%, same locality as holotype, 24.xii.1977; 5o', 6\%, $100 \mathrm{~km}$ E. of Hughenden, 26-30.iii.1976, R. I. Storey; 50*, 7\%, $16 \mathrm{~km}$ E. of Emerald, 30.xii.1974, R. I. Storey; 20, $20 \mathrm{~km} \mathrm{SE}$. of Roma, 3.iii.1982, M. Porter; $1 \%$, $30 \mathrm{~km}$ E. of Morven, 2.iii.1982, M. Porter; $1 \%$, 1\%, Charleville, 2.iv.1975, P. Allsopp; $20^{\circ}, 1$ \%, Edungalba, Mar. 1975, D. Smith; 2ф, 'Separation', Edungalba, Jan. 1975, Smith; 1\%, Marlborough, 4.vi.1981, K. G. Asher; 20, 3\%, Dawson R. New South Wales: 1\%, Bogan R. Paratypes in: ANIC, ANIC (MMUS), PGAC, QDIPM, QM, QUE, SAMA.
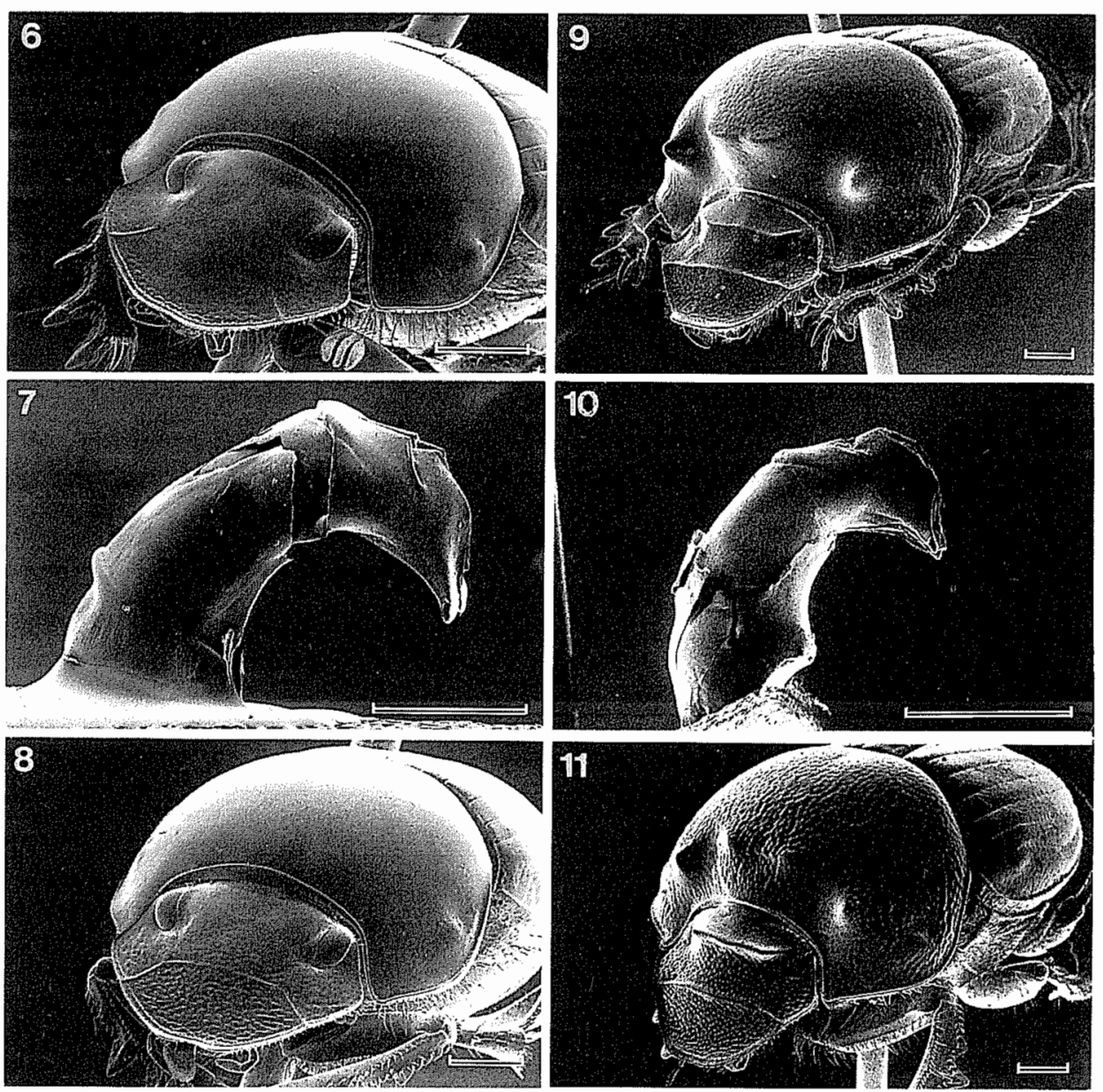

Figs 6-8. Onthophagus kakadu: 6 , head and pronotum, male; 7 , aedeagus; 8 , head and pronotum, female.

Figs 9-11. Onthophagus worooa: 9, head and pronotum, male; 10, aedeagus; 11 , head and pronotum, female.

Scale lines: $6,8,9-11,1.0 \mathrm{~mm} ; 7,0.5 \mathrm{~mm}$. 


\section{Description}

Fore body (except clypeus), pygidium green or cupreous, legs with slight greenish reflections, rest of body black, antennal clubs fulvous. Total length $8 \cdot 2-11 \cdot 7 \mathrm{~mm}$.

\section{Male}

Head. Clypeal margin medially broadly truncate, feebly bilobate in some, reflexed, rest of margin straight to genal angles which are projecting and rounded. Clypeal suture complete, nearly straight. Frontal carina low, sinuate, reaching base of eyes. Eyes dorsally about 10 facet rows in width, separated by about 11 eye widths, canthus complete. Surface moderately punctate, clypeus feebly rugose, glabrous. Labium excised two-thirds of way to base.

Pronotum. Convex, front with a transverse row of four prominences, distance between middle pair being about two-thirds to half that between middles and laterals, middle pair united to form a low sinuate prominence, especially in major male, lateral pair small and conical; reduced to condition of female in minor male. Anterior angles rounded, apices turned out, acute. Hind edge margined. Moderately punctate on disc, reduced in front of prominences and near hind edge, surface between smooth, nitid, glabrous.

Elytra. Intervals slightly convex, smooth, shagreened tending towards nitid at humeri and apices, glabrous, sparse fine punctures. Striae moderately impressed, geminate, punctures moderate.

Legs. Fore tibiae elongate, curved distally in major male and expanded opposite apical tooth. Inner apical angle with clump of setae nearly as long as spur.

Abdomen. Pygidium variable, shagreened, fine to moderate punctures, glabrous in some, sparse setae in others. Aedeagus as in Fig. 10.

\section{Female}

Clypeus not reflexed, feebly bilobate, surface of clypeus more rugose, frontal carina more prominent. Pronotal prominences small, almost effaced in smaller specimens, equidistant, punctures coarser, rugose towards sides. Fore tibiae normal. Otherwise like male.

\section{Distribution (Fig. 3)}

In eastern inland areas, from between the $840 \mathrm{~mm}$ and $1120 \mathrm{~mm}$ isoyets in northern areas to west of the $560 \mathrm{~mm}$ isoyet in central New South Wales, only one record on the coast. Usually in sandy soil, at wallaby and cow dung, or trapped with human excrement baits. One Charleville specimen was taken in a mushroom.

\section{Comments}

Specimens from Hughenden south have a coppery sheen, the clypeal margin feebly bilobate and the centre pronotal prominences further apart in the major male. This and the following new species are closely related to $O$. tricavicollis Lea but they can easily be separated in the major males. The following modifications to Matthews' (1972) key to species of the conspicuus group should aid in the separation of the three species.

6(5). Pronotum very strongly and closely punctate, producing cribrate (not rugose) surface; punctures on anterior part of pronotum with long setae, rest with short stubble; elytra with dense stubble; N.T. ....................................

Pronotum with relatively small to moderate punctures, surface between them smooth to rugose, especially in minor male and female; elytra and pronotum glabrous

6a(6). Elytral intervals shining, feebly rugose; major male with very prominent median pronotal protuberances, higher than wide; $\mathrm{n}$. Qld ........................ O. tricavicollis Lea

Elytral intervals shagreened, smooth; major males with low median pronotal protuberances,

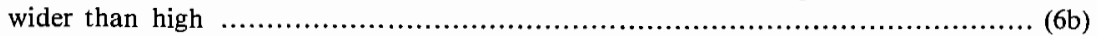

6b(6a). Frontal carina of major male effaced; genal angles arcuate, not protruding; pronotum rugose between moderate punctures; n. Qld ............................ O. mongana, sp. nov. 
Frontal carina of major male in the form of a low ridge; genal angles quadrate, protruding; pronotum smooth between relatively small punctures; N.S.W. to n. Qld

O. worooa, sp. nov.

Onthophagus mongana, sp. nov.

(Figs 12-14)

\section{Material Examined}

Holotype. ơ, Queensland: Davies Creek, Mareeba, 4-8.ii.1976, R. I. Storey, in QM, T10 893.

Paratypes. (41), Queensland: $13 \sigma^{\circ}, 2 \wp$, same data as holotype, $7 \sigma^{\circ}, 8 \%$, same locality as holotype, 14-20.ii.1981; 10 , Southedge, via Mareeba, 23.xi.1976, R. I. Storey; $20^{\circ}$, same data, 20.xii.1976, 1 q, same data, 1.ii.1977, 1\%, same data, 1.iii.1977; 10", Watsonville, via Herberton, 22-27.iii.1980, R. I. Storey; 5o, 1\%, $12 \mathrm{~km}$ W. of Herberton, 11-15.ii.1979, R. I. Storey. Paratypes in: ANIC, QDIPM, QM, SAMA.

\section{Description}

Black, pronotum and head (except clypeus) green or bluish-green, antennal clubs fulvous. Total length $8 \cdot 8-11 \cdot 1 \mathrm{~mm}$.

Male

Head. Clypeal margin medially produced, reflexed, feebly bilobate in major male, truncate in minor, rest of margin straight, slightly elevated just before genal angles which are not prominent, feebly rounded to eye. Clypeal suture feebly carinate, almost straight, genal sections slightly angled to median section. Frontal carina low in minor male, effaced in major male, represented by three slight tumescences, one in centre and one near each eye. Eyes dorsally 10-11 facet rows in width, separated by 9-12 eye widths, canthus complete. Surface with numerous medium punctures, fine on back of frons, clypeus very feebly rugose, glabrous. Labium excised two-thirds of way to base.

Pronotum. Convex, with transverse row of four prominences, outer two small, acute, about one-third distance to midline, inner two large, widely separated rounded lobes, slightly downturned at apex, about half distance to midline, separated by a broad ' $V$ '; broad shallow depressions occupying space in front of prominences to apices. Anterior angles quadrate, apices acute, lateral angles prominent, quadrate, rounded. Reduced to condition of female in minor male. Hind edge margined. Numerous coarse punctures on disc, rugose, finely punctate in front of middle prominences, very finely punctate in depressions, glabrous.

Elytra. Intervals slightly convex, shagreened, very finely punctate, glabrous. Striae moderately impressed, punctures small.

Legs. Fore tibiae long, narrow, slightly expanded between 2nd and 3rd tooth, teeth small, apical brush of long setae 2-3 times length of spur. Modifications reduced in minor male.

Abdomen. Pygidium shagreened, nitid in centre, scattered coarse punctures, small setae on sides. Aedeagus as in Fig. 13.

\section{Female}

Clypeal margin truncate, not reflexed. Clypeus and frons more coarsely punctate, clypeus rugose, frontal carina prominent, straight, not reaching eyes. Pronotal prominences greatly reduced, effaced in some specimens, two pairs of tumescences in others, lateral angles not prominent. Pronotal surface more coarsely punctate, rugose over entire surface. Fore tibiae not modified, Otherwise like male.

\section{Distribution (Fig. 3)}

Known from the Atherton Tableland at three localities with granite soil and Eucalyptus woodland vegetation. At Davies Creek it was taken together with the related species $O$. tricavicollis. All specimens taken at human excrement baits. 


\section{capella group}

Onthophagus cooloola, sp. nov.

(Figs 15-17)

\section{Material Examined}

Holotype. ơ, Queensland: Cooloola S.F., via Gympie, 25-26.xii.1974, R. I. Storey, in QM, T10 889.

Paratypes. (53), Queensland: 3o*, 2o, same data as holotype, 3o*, 3o, same data, 19-20.x.1974, 3ơ, 3o, same data, 25-27.iv.1975, 3o, same data, 9.xi.1974, G. B. Monteith; $100^{*}$, 9o, same data,

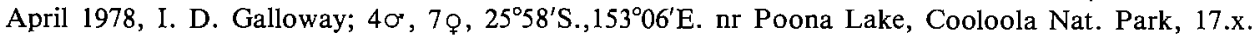
1978, D. C. F. Rentz and J. Balderson; $1 \sigma, 1 \%$, Poona Lake area, Cooloola, 17.x.1978, G. B. Monteith; lo, Camp Milo, Cooloola, 15-18.x.1978, G. B. Monteith. Paratypes in: ANIC, QDPI, QDPIM, QM, QUE, SAMA.

\section{Description}

Black, antennal clubs flavous to fulvous. Total length $7 \cdot 4-10 \cdot 4 \mathrm{~mm}$.
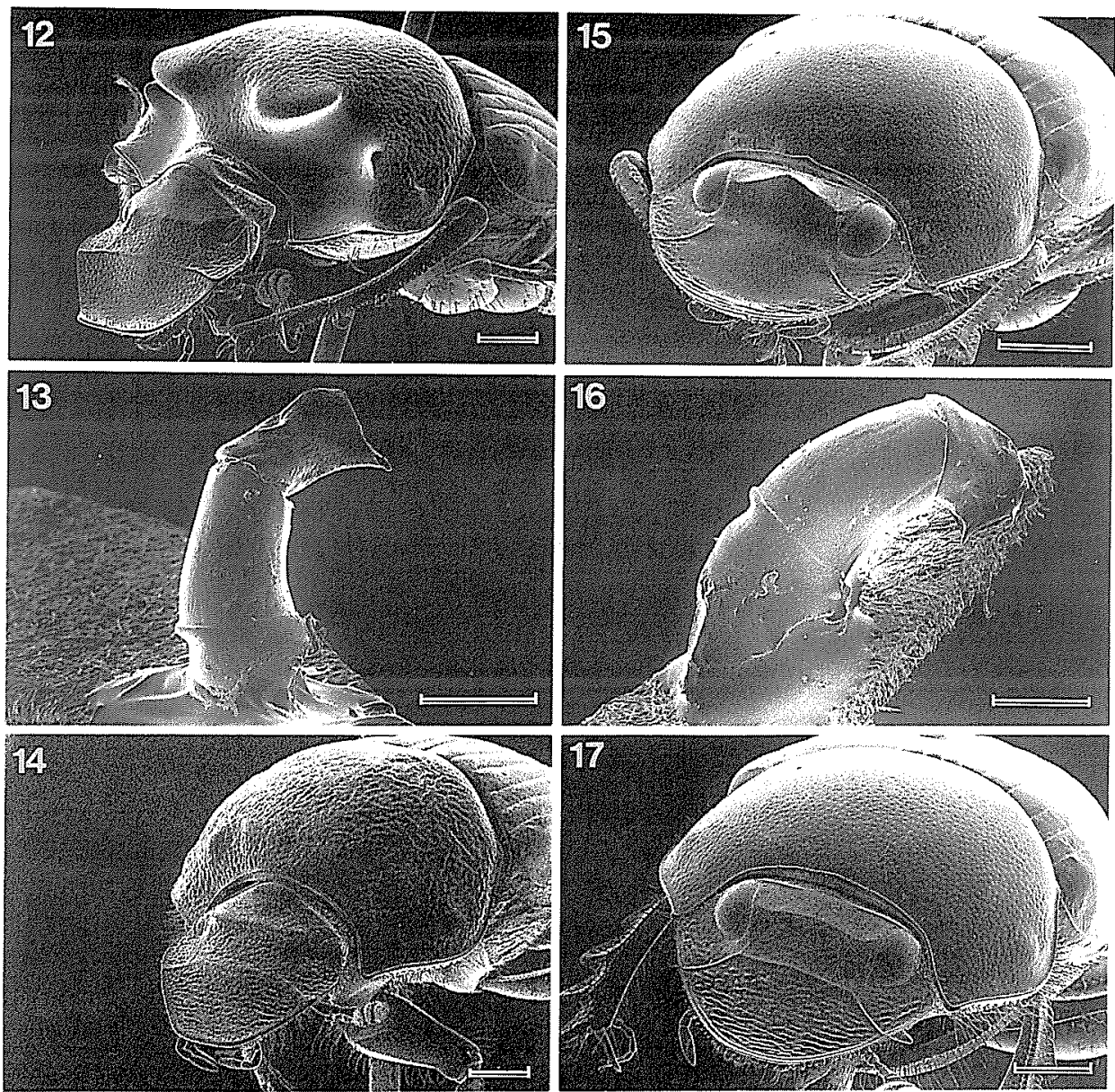

Figs 12-14. Onthophagus mongana: 12, head and pronotum, male; 13, aedeagus; 14, head and pronotum, female.

Figs 15-17. Onthophagus cooloola: 15, head and pronotum, male; 16, aedeagus; 17, head and pronotum, female.

Scale lines: $12,14,15,17,1 \cdot 0 \mathrm{~mm} ; 13,16,0.5 \mathrm{~mm}$. 
Male

Head. Clypeal margin slightly reflexed medially, evenly rounded to genal angles, these slightly protruding, subangulate. Clypeal suture with frontal section effaced in major male, scarcely discernible in minor, genal sections at right angles to edge of clypeus, finely carinate. Frons with a short carina, raised medially to form a low vertical angular process, tapering to a point, about one-third of distance between eyes in height; reduced to a low sinuate transverse carina in minor males. Eyes dorsally about 25 facet rows in width, separated by $3 \cdot 5-4$ eye widths, canthus complete. Surface nitid, glabrous, frons and centre of clypeus smooth, very finely punctate, clypeal margins and genal angles transversely rugose. Labium excised nearly halfway to base.

Pronotum. Anterior half feebly more convex than posterior half in major male; feebly impressed, evenly convex in minor, unsculptured. Anterior angles quadrate, apices slightly turned out. Lateral margins slightly sinuate, hind edge not margined. Surface moderately punctate with small punctures separated by 1-3 diameters, glabrous, nitid, shagreened towards sides and apical angles.

Elytra. Intervals nitid towards sides, shagreened in central area, feebly convex, finely punctate, especially towards sides, glabrous. Striae geminate, moderately impressed with shallow punctures.

Legs. Fore tibia slightly elongate with apical brush of short setae about length of spur.

Abdomen. Pygidium nitid in centre, shagreened towards base, moderately punctate with small punctures, separated by 1-2 diameters, glabrous. Aedeagus as in Fig. 16.

\section{Female}

Clypeal margin not reflexed, end slightly flattened. Clypeal suture carinate, closer to frontal carina than apex of clypeus. Clypeus entirely transversely rugose. Frontal carina strong, straight or feebly sinuate. Pronotum evenly convex. Fore tibiae normal. Otherwise like male.

\section{Distribution (Fig. 5)}

Known only from Cooloola State Forest in south-east Queensland, in closed forest growing on sand. Those taken by Storey were trapped with human excrement bait. It has not been taken in similar country on Fraser Island to the north of Cooloola despite bait trapping for Scarabaeinae.

\section{Comments}

This species is best placed in the capella group near $O$. neostenocerus Goidanich and $O$. dicranocerus Gillet, both large-eyed rainforest species to which it runs in Matthews' (1972) key. It can be separated from both these species by the male cephalic armament which is a low tapered point in $O$. cooloola, a pair of long slender horns in $O$. neostenocerus and a long bifurcate horn in $O$. dicranocerus. In the female of $O$. cooloola the clypeal suture is closer to the frontal suture than to the apex of the clypeus and about halfway between in the other two species. Both sexes have a less convex more coarsely punctate pronotum. $O$. cooloola also has similarities to the pronus group in its effaced clypeal suture and slightly elongate fore tibia in the male. It is possibly somewhat intermediate between these two closely related groups.

Onthophagus williamsi, sp. nov.

(Figs 18-20)

\section{Material Examined}

Holotype. $\sigma^{\circ}$, New South Wales: Moppy Lookout Rest Area, NE. Section Barrington Tops S.F., 20-21.xii.1983, G. Williams, in ANIC, ANIC No. 101.

Paratypes. (10), New South Wales: $1 \sigma^{*}, 3$, same data as holotype, 1\%, same data, 21.i.1981, G. and T. Williams, $1 \%$, same data, 27.xii.1982, G. and T. Williams, $1 \sigma^{\circ}, 3 \%$, same data, 2930.xii.1986, G. and B. Williams. Paratypes in: ANIC, GWC, QDPIM. 


\section{Description}

Black, underside and legs rufopiceous, antennal clubs fulvous, pilosity pale brown. Total length $12 \cdot 8-16 \cdot 0 \mathrm{~mm}$.

Male

Head. Clypeal margin strongly produced forward, reflexed, apically truncate, with sides slightly concave meeting genal margin at a sharp angle about frontal suture. Genal margin slightly convex, genal angle not evident. Clypeal suture carinate, not divided into frontal and genal sections, strongly bent backwards medially. Vertex with a broad lamina strongly inclined backwards, lamina branching into two flattened processes which apically give rise abruptly to a tapering horn, bent slightly forward. Margin between flattened processes evenly arcuate with a small triangular anterior projection in middle. Eyes dorsally about 10 facet rows in width, separated by about 12 eye widths, canthus complete. Clypeus transversely rugose, less so on apically reflexed part, genae in front of eyes densely but shallowly punctured, rest of head with scattered very fine punctures, smooth, shining, glabrous. Labium excised about one-third of way to base.

Pronotum. Convex, with a median, longitudinal ridge running from anterior edge to posterior edge of anterior declivity, here ending in a sharp point. Anterior angles quadrate, rounded. Hind edge distinctly margined. Surface densely punctate, punctures tending to run together in longitudinal rows, anterior declivity very finely punctate, smooth, glabrous, shining.

Elytra. Intervals flat, shagreened, rugose, humeri and apices of intervals 3-6 shining, glabrous except for scattered setae along all of last interval. Striae superficial, finely and indistinctly punctate.

Legs. Fore tibiae not modified.

Abdomen. Pygidium shining, finely shagreened in basal angles, moderately punctate with large shallow punctures, each bearing a pale brown seta of moderate length, glabrous along midline. Aedeagus as in Fig. 19.

\section{Female}

Clypeus not produced or medially reflexed, more rounded, sides nearly straight, rugose over whole surface. Clypeal suture less bent back in middle and slightly raised either side of middle. Vertex with lamina not as strongly inclined, smaller, ending in two parallel horns, blunt, vertically directed, margin between flattened, processes not arcuate, with an inwardly directed tooth on either side, anterior triangular projection narrower; minor female with horns much reduced and without inner teeth. Pronotum with smaller anterior declivity and shorter median ridge but with a distinct small swelling on either side of posterior edge of ridge and in a transverse line with it; minor female with very small anterior declivity, ridge and swellings. Fore tibiae normal. Otherwise like male.

\section{Distribution (Fig. 4)}

Known only from the type locality $\left(31^{\circ} 54^{\prime} \mathrm{S} ., 151^{\circ} 33^{\prime} \mathrm{E}\right.$.), trapped with human excrement bait in closed forest dominated by Nothofagus moorei, at an altitude of approximately $1300 \mathrm{~m}$.

\section{Comments}

This species will not key out satisfactorily in Matthews' (1972) key to species groups. The setae on the pygidium and the last elytral interval would, at first glance, seem to exclude it from the capella group. However, O. comperei Blackburn is keyed out separately as having setae on the pygidium and in fact setae are also present on the pygidium of four other members of the capella group, namely $O$. macrocephalus Kirby, O. mamillatus Lea, $O$. mundill Matthews and $O$. darlingtoni Matthews. These setae are apparently easily rubbed off as the majority of specimens examined have only a few remaining. $O$. williamsi, 
is placed in the capella group on the basis of possessing almost all of the other characters of the group as defined by Matthews (1972), i.e. eyes narrow to wide, with 11-30 facet rows across widest point, separated by 3-10 eye widths, canthus complete; labium excised about halfway to base; colour entirely black; total length 6-17 mm; male with frontoclypeal suture carinate, vertex armed; pronotum usually armed; fore tibiae not elongate, without distal seta brush; female with a crest or strong carina on vertex, pronotum usually armed. $O$. williamsi occupies a rather isolated position in the capella group and can be readily separated from all other species in the group by a combination of recurved clypeal suture, shape of head armament in male and female, median longitudinal ridge on pronotum and setae on pygidium and last elytral interval.

\section{dunningi group}

Onthophagus pinaroo, sp. nov.

(Figs 21-23)

\section{Material Examined}

Holotype. O', Queensland: Ewan Rd, $8 \mathrm{~km}$ W. of Paluma, 7.xii.1970, J. G. and J. A. Brooks, in ANIC, ANIC No. 96.
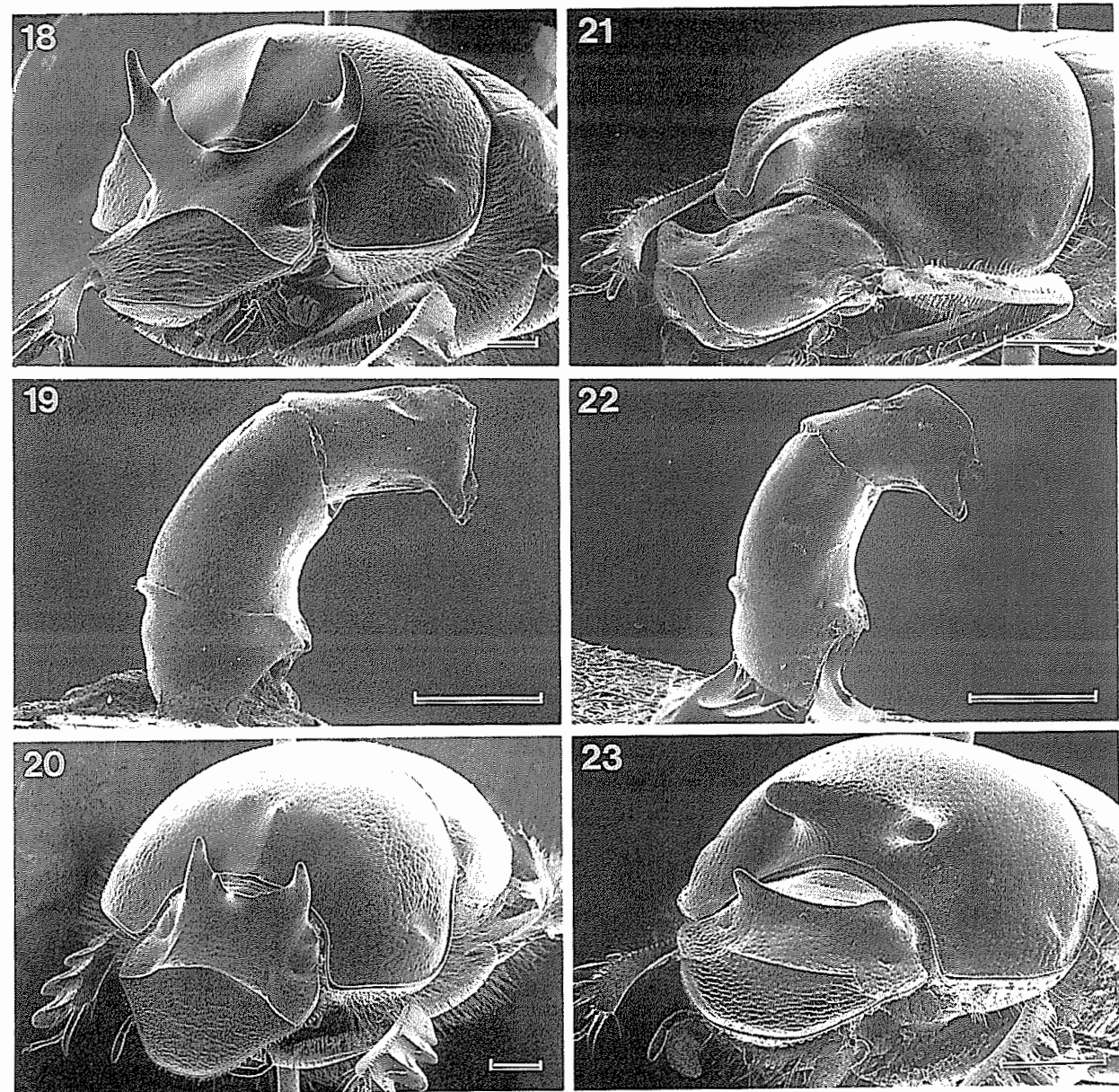

Figs 18-20. Onthophagus williamsi: 18, head and pronotum, male; 19, aedeagus, 20, head and pronotum, female.

Figs 21-23. Onthophagus pinaroo: 21 , head and pronotum, male; 22, aedeagus; 23, head and pronotum, female.

Scale lines: $18-21,23,1 \cdot 0 \mathrm{~mm} ; 22,0.5 \mathrm{~mm}$. 
Paratypes. (35), Queensland: 4\%, same data as holotype; $1 \sigma^{\circ}$, Ewan Rd, 4-13 km W. of Paluma, 14.i.1970, J. G. Brooks; $2 \sigma^{\circ}$, same data, 7.xii.1970, 2o, 4\%, same data, 16.xii.1971, $1 \sigma^{\circ}$, same data, 12.xii.1972, 1\%, same data, 14.xii.1972, 2q, same data, 6.xi.1973, $1 \circ$, 3申, same data, 7.xi.1973, 3\%, same data, 4.xii.1973, 1 , same data, 24.ii.1974; 3o, 11-13 km W. of Paluma, 23.ii.1972, J. G. Brooks; 1 $\sigma, 1 \%$, same data, 7.ii.1973; 1 $\sigma$, 1\%, Paluma, 3.xii.1969, A. Walford-Huggins; 1\%, Mt Spec., 11.i.1968, J.G.B.; 10 , $5 \mathrm{~km} \mathrm{N.} \mathrm{of} \mathrm{Herberton,} \mathrm{14-15.ii.1976,} \mathrm{R.} \mathrm{I.} \mathrm{Storey;} 1 \sigma^{\circ}$, Windsor Tableland, $30 \mathrm{~km}$ from main road, 15.i-15.iii.1986, Storey and Brown. Paratypes in: ANIC, AWHC, QDPIM, QUE, SAMA.

\section{Description}

Rufopiceous, almost black, antennal clubs dark yellow. Total length $7 \cdot 3-9 \cdot 4 \mathrm{~mm}$.

\section{Male}

Head. Middle of clypeal margin of major male produced into a long, erect, narrow process, almost parallel sided, apex rounded, rest of clypeal margin expanded, convex to genal margin, genae expanded, quadrate, rounded. Frontal section of clypeal suture effaced in major male, finely beaded in minor, genal sections beaded. Frons unsculptured in major male, minor with a suture raised into low points near eyes. Eyes dorsally about eight facet rows in width, separated by about 10 eye widths, canthus complete. Surface smooth, shagreened, finely punctate, coarser along edge of clypeus; punctures coarser in minor male. Labium emarginate.

Pronotum. Convex, armed with a forward projecting, median, angular, tapering process, apical one-third of which is downturned, about level of the clypeal suture, apex truncate, emarginate, slightly expanded, the whole process flattened, depressed on top; reduced to a short emarginate process in minor male. Anterior angles quadrate, apices rounded in major male, margin expanded just before apices in major male; angles acute, angular margin not expanded in minor male. Hind edge not margined. Surface of disc with fine punctures, grading to coarse on process, reduced in front of process, glabrous.

Elytra. Intervals flat, shagreened, finely punctate, glabrous. Striae fine, geminate, with fine punctures.

Legs. Fore tibiae elongate, slightly curved inwards on apical one-quarter with tuft of setae a bit longer than spur; unmodified in minor male.

Abdomen. Pygidium flattened, shagreened, punctures fine, sparse setae near edges. Aedeagus as in Fig. 22.

\section{Female}

Clypeal margin not expanded, no median process, genae not prominent. Frontal section of clypeal suture carinate, arcuate. Frons with a transverse carina, ends elevated into rounded points near eyes. Surface smooth, nitid, clypeus rugose. Pronotum with short median process, with lateral rounded extensions, producing a broadly bifurcate appearance, reduced in smaller specimens. Anterior apices quadrate, rounded, sides of pronotum not expanded. Fore tibiae normal. Otherwise like male.

\section{Distribution (Fig. 4)}

Known only from the Paluma area and Atherton Tableland. Most specimens were taken by J. G. Brooks at decaying fish, but one specimen was taken near Herberton in a trap baited with decaying mushrooms and one specimen was taken at human excrement. There is little doubt that this species, a northern relative of $O$. dunningi Harold, prefers mushrooms as a food source, as do all members of the dunningi species group.

\section{Comments}

This species runs to $O$. dunningi in Matthews' (1972) key to the dunningi group and is very similar in general appearance, causing that author to group females of $O$. pinaroo, the only specimens then available, under that species. It is now clear that females of 
O. pinaroo have the frontal carina stronger, with the ends raised into distinct points, and the pronotal process developed into a bifurcate process in larger individuals. Males of the two species can be distinguished by the prominent genae, the expanded quadrate anterior pronotal angles and flattened downturned pronotal horn in $O$. pinaroo.

\section{australis group}

Onthophagus yourula, sp. nov.

(Figs 24-26)

\section{Material Examined}

Holotype. ơ, Queensland: Bald Mtn, via Emu Vale, 27-29.i.1973, R. I. Storey, in QM, T10 898.

Paratypes. (41), Queensland: $30^{\circ}, 3 \circ$, same data as holotype, $1 \sigma^{\circ}$, same data 28.i.1972; $1 \sigma^{\circ}$, Mt Lindsay Hwy, $22 \mathrm{~km} \mathrm{~S}$. of Rathdowney, 24-25.ii.1973, R. I. Storey; 2@, Cunningham's Gap, 13.i.1972, R. I. Storey, 6o , 5\%, same data, 17-19.i.1973; 1 $\sigma^{\circ}$, Toowoomba, 21.iii.1975, H. and A. Howden; $1 \sigma^{\circ}$, Mistake Mtns, via Laidley, 10-11.ii.1973, G. B. Monteith, 1 $\sigma^{\circ}$, 1\%, same data, R. I. Storey; $10^{\circ}, 1$, Blackbutt Range, $10 \mathrm{~km}$ E. of Blackbutt, 22-23.xii.1973, R. I. Storey; $1 \sigma^{\circ}$, $1 \%$, Bunya Mtns, Jan. 1931, E. Sutton; 3o , 3\%, same data, 17.iii.1975, P. Allsopp; $1 \sigma^{\circ}, 26^{\circ} 50^{\prime}$ S., $151^{\circ} 33^{\prime} \mathrm{E}$., Bunya Mtns, $5 \mathrm{~km} \mathrm{NW}$. of Mt Mowbullan, 8.i.1970, Britton, Holloway, and Misko; 10 , Howie prop, Eungella, 15.xii.1976, A. Macqueen. New South Wales: 1o*, Roseville, 8.iii.1972, C. E. Chadwick; 1 o, Asquith, 15.ix.1987, A. L. Dyce; 10*, Yabbra S.F., 8 km S. of Urbenville, 8-9.xii.1973, R. I. Storey; 10, Mt Lindsay S.F., 24-25.ii.1973, R. I. Storey. Paratypes in: ANIC, HFHC, PGAC, QDPI, QDPIM, QUE.

\section{Description}

Black with cupreous reflections, antennal clubs flavous. Total length $6 \cdot 8-9 \cdot 9 \mathrm{~mm}$.

\section{Male}

Head. Clypeal margin rounded, slightly flattened in middle, very slightly convex before genae, genae rounded. Clypeal suture complete, frontal section arcuate. Vertex in major male with a pair of long curved horns, one near each eye, divergent except apex which is turned inwards, slight tumescence in centre of a line between horns; horns absent in minor male, replaced by slight tumescences. Eyes dorsally 7-9 facet rows in width, separated by 11-13 eye widths, canthus incomplete. Numerous coarse punctures over entire surface except horns and area behind, clypeus rugose, glabrous. Labium excised one-third of way to base.

Pronotum. Convex, slight depression behind each head horn and a swelling between in major male; evenly convex in minor male with two very slight tumescences behind head. Anterior angles quadrate, apices slightly prominent. Hind edge feebly margined. Numerous medium-sized punctures over surface of disc, sparser and finer behind horns in major male and near anterior angles, surface shagreened, except behind horns and anterior angles which tend toward nitid, glabrous; punctures coarser in minor male.

Elytra. Intervals feebly convex, shagreened, with numerous fine punctures, slight swelling at base of $2 \mathrm{nd}, 3 \mathrm{rd}$ and 4 th intervals, glabrous. Striae shallow, geminate, nitid, punctures fine.

Legs. Fore tibiae slightly elongate in major male.

Abdomen. Pygidium slightly convex, shagreened, scattered setiferous punctures over surface except along midline. Aedeagus as in Fig. 25.

\section{Female}

Clypeus more elongate, punctation denser on frons. Frons with low recurved, arcuate carina, not reaching eyes, higher at ends, slight tumescence in centre. Pronotal punctures coarser, more numerous, pair of slight tumescences at front of pronotum behind head, centre line slightly raised. Fore tibiae normal. Otherwise like male. 


\section{Distribution (Fig. 4)}

Known from New South Wales and south-east Queensland except for a single specimen from Eungella in central Queensland which is a minor male. Taken in montane closed forest and adjacent wet sclerophyll, trapped with human and pig excrement baits and collected in cow dung.

\section{Comments}

This species is easily separated from other members of Matthews' (1972) australis group by the lack of a lamina between the head horns in the male. Females are very similar to those of $O$. australis Guérin-Méneville and $O$. nurubuan Matthews but can be separated from them by the glabrous elytra and strong coppery colour.

\section{Onthophagus weringerong, sp. nov.}

(Figs 27-29)

\section{Material Examined}

Holotype. O', Queensland: Bald Mtn area, via Emu Vale, 27-29.i.1973, R. I. Storey, in QM, T10 895.
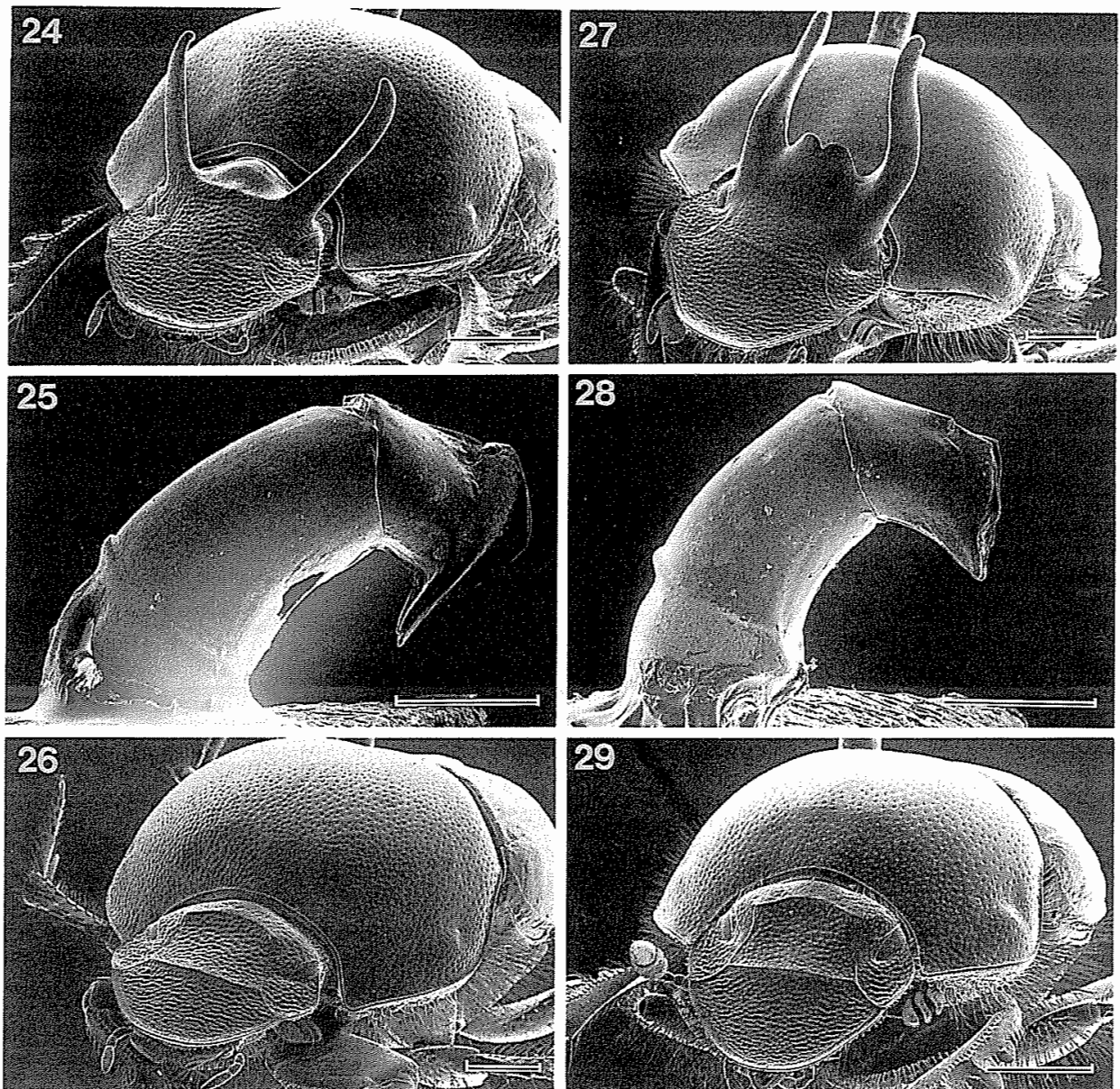

Figs 24-26. Onthophagus yourula: 24 , head and pronotum, male; 25 , aedeagus; 26 , head and pronotum, female.

Figs 27-29. Onthophagus weringerong: 27 , head and pronotum, male; 28 , aedeagus; 29 , head and pronotum, female.

Scale lines: $24,26,27,29,1.0 \mathrm{~mm} ; 25,28,0.5 \mathrm{~mm}$. 
Paratypes. (24), Queensland: $9 \sigma^{\circ}, 6 \circ$, same data as holotype, $1 \sigma^{*}$, same data, 17-22.v.1969, A. B. Graham; 1o*, same data, 26-30.i.1973, G. B. Monteith; 1q, Hampton, 2.xii.1973, P. Allsopp. New South Wales: $1{ }^{*}, 1 \%$, Tooloom Plateau, via Urbenville, 24-25.ii.1973, R. I. Storey; 20*, 1\%, Wiangaree S.F., 600 m, Sheepstation Ck, 29.ii-3.iii.1980, A. Newton and M. Thayer; $10^{*}$, Buladelah S.F., Buladelah, 6.i.1978, G. and T. Williams. Paratypes in: ANIC, GWC, QDPIM, QM, QUE.

\section{Description}

Black, very faint cupreous reflections, pygidium greenish, antennal clubs flavous. Total length $6 \cdot 2-10 \cdot 4 \mathrm{~mm}$.

\section{Male}

Head. Clypeal margin moderately produced medially, reflexed, truncate, sides straight except slight swelling just before genae, less so in minor male, genae rounded. Clypeal suture with frontal section effaced in major male, beaded in others. Vertex with convex, elevated lamina, crest rounded, emarginate, flanked by two horns, about twice height of lamina, placed one near each eye, each horn wider, flattened on basal half, apical half thin, rounded, tip blunt. Shape of horn gradually tapering, diverging at base, then converging on basal three-quarters of length, apical one-quarter straightening, the pair of horns being thus lyre shaped; centre lamina and horns reduced in minor males, completely absent in some. Eyes dorsally 8-9 facet rows in width, separted by 10-12 eye widths, canthus complete. Surface of clypeus and genae with numerous coarse punctures, clypeus rugose, punctures on frons fine, scattered, surface of armament nitid. Labium excised one-third of way to base.

Pronotum. Convex in major male; anterior half flattened, shape less convex, unsculptured in minor male. Anterior angles quadrate, margin behind sinuate. Hind edge margined. Punctures on disc sparse, very fine on anterior half nitid; numerous medium punctures on posterior half, these very distinct with nitid centres, glabrous.

Elytra. Intervals slightly convex, shagreened, with scattered fine punctures, short setae on basal one-quarter of last interval. Striae shallow, geminate, punctate, nitid.

Legs. Fore tibiae moderately elongate.

Abdomen. Pygidium with scattered medium setiferous punctures over entire surface, shagreened. Aedeagus as in Fig. 28.

\section{Female}

Clypeal margin not produced or reflexed, clypeal suture carinate. Frons with low, recurved, arcuate carina, punctures more numerous, coarser. Pronotum with slight depression only behind head, less convex, punctures more numerous, coarser, over entire surface. Fore tibiae normal. Otherwise like male.

\section{Distribution (Fig. 3)}

Northern New South Wales and south-east Queensland, in higher altitude open forest. Trapped with human excrement baits.

\section{Comments}

This species is close to $O$. thoreyi Harold and keys to that species in Matthews' (1972) key to the australis species group. It can be separated from $O$. thoreyi by the lyre shaped armature in the male and by the shape of the central lamina. Both sexes have the surface of the pronotum shagreened instead of nitid and the punctures more distinct. The elytral intervals of $O$. wereingerong also have larger, more numerous punctures. Its distribution is somewhat to the south of that of $O$. thoreyi. 
auritus group

Onthophagus beelarong, sp. nov.

(Figs 30-32)

\section{Material Examined}

Holotype. O*, Queensland: Cooloola S.F., via Gympie, 19-20.x.1974, R. I. Storey, in QM, T10 887.

Paratypes. (55), Queensland: $60^{\circ}, 13 \%$, same data as holotype, 1 , same data, 25-27.iv.1975; $80^{\circ}, 60$, Yidney Scrub, Fraser Island, 1-4.xii.1975, G. Thompson and J. A. Slater; 40*, Bob Gully, Fraser Island, 29-30.xi.1975, G. Thompson and J. A. Slater; 70, 10ᄋ, Lake Coomboo, Fraser Island, 5.v.1975, H. Burton. Paratypes in: ANIC, QDPIM, QM, QUE.

\section{Description}

Shiny black, head (except clypeus in female) and pronotum shiny blue or blue-green, antennal clubs flavous, pilosity pale to light yellow. Total length $6 \cdot 6-9 \cdot 2 \mathrm{~mm}$.
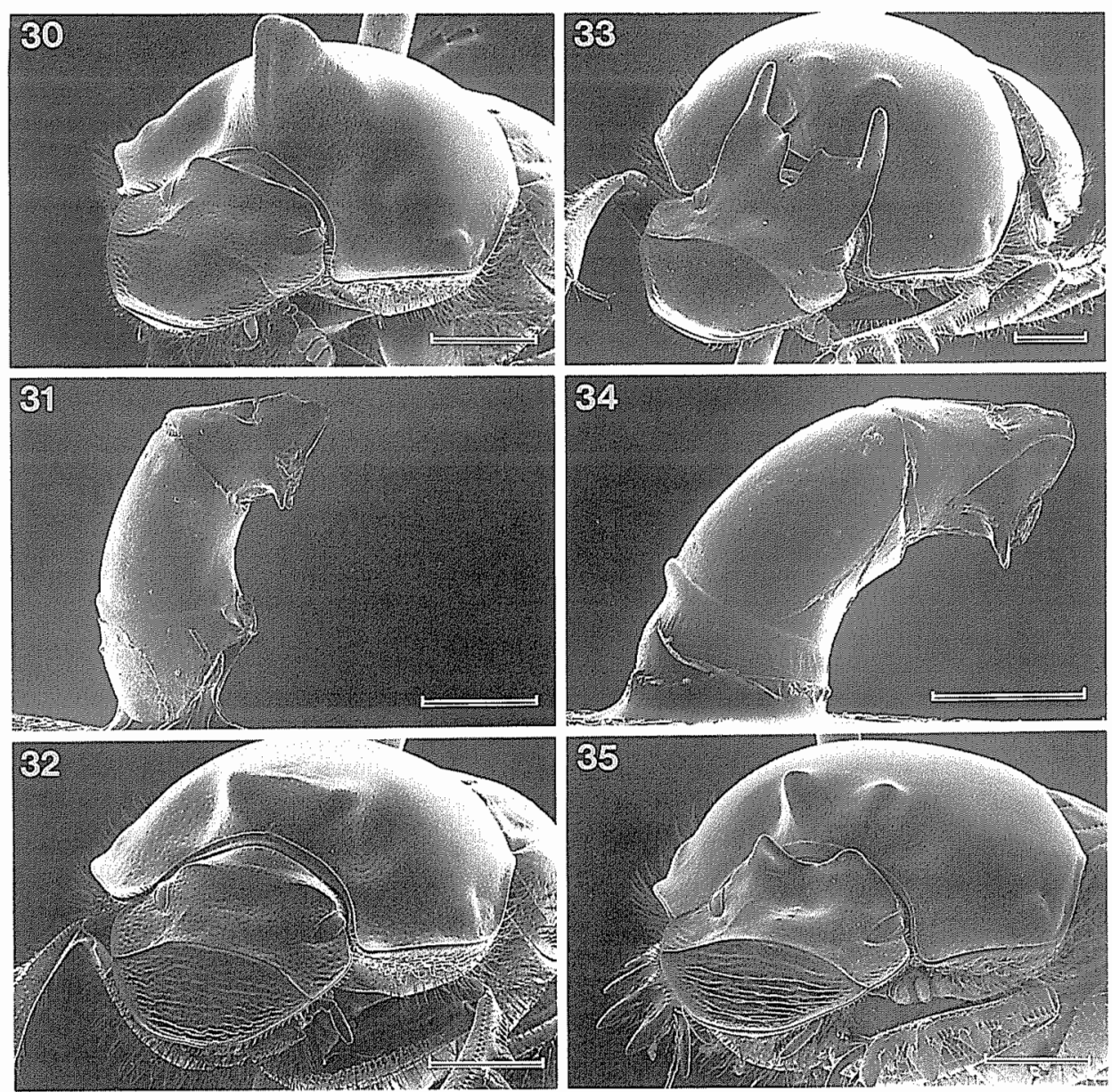

Figs 30-32. Onthophagus beelarong: 30 , head and pronotum, male; 31 , aedeagus; 32 , head and pronotum, female.

Figs 33-35. Onthophagus gurburra: 33, head and pronotum, male; 34, aedeagus; 35, head and pronotum, female.

Scale lines: $30,32,33,35,1 \cdot 0 \mathrm{~mm} ; 31,34,0.5 \mathrm{~mm}$. 
Male

Head. Clypeal margin medially prolonged, reflexed, less so in minor males which are sometimes feebly emarginate, lateral margins expanded slightly just before genae, genae rounded. Clypeal suture with frontal section very faint, almost effaced. Vertex with very low carinate fold across back of head between eyes, strongest near eyes, effaced in centre. Eyes dorsally 9-11 facet rows in width, separated by 8-12 widths, canthus complete. Edge of clypeus rugose, rest of head very smooth, nitid, less so in minor male, punctures minute to fine, frons and genae moderately punctate, glabrous. Labium excised one-third of way to base.

Pronotum. Convex, major male with median, tapering process, slightly upturned on apical one-third, dorsally flattened, underside with a shallow groove; apex truncate tending towards bifurcate in minor males, smallest specimens as in female. Anterior angles protruding, apices rounded, lateral margins of pronotum sinuate. Hind edge finely margined. Surface with sparse very fine punctures, front of process with numerous moderate punctures, faint line on centre of disc from apex of process to hind edge, very nitid, glabrous.

Elytra. Intervals flat to slightly convex with numerous fine punctures, base of 2nd, 3rd and 4th intervals and humeral area slightly swollen, centre of 7 th interval with slight swelling, setiferous punctures on basal half of last interval, setae long, pale, curved, surface very nitid. Striae very fine with moderate, crenulating punctures.

Legs. Fore tibiae slightly elongate

Abdomen. Pygidium moderately punctate, nitid, with long silvery pilosity except apical one-quarter which is finely punctate, glabrous. Aedeagus as in Fig. 31.

\section{Female}

Clypeus black, strongly, transversely rugose, margin not prolonged medially, feebly emarginate. Clypeal suture carinate, genae rugose. Fold on vertex effaced in middle onethird. Frons finely punctate, smooth, nitid. Front of pronotum with a broadly truncate lobe, sides of which are feebly drawn out into blunt corners, centre feebly depressed, flanked by shallow depression behind each eye, lobe less prominent in smaller specimens. Fore tibiae normal. Otherwise like male.

\section{Distribution (Fig. 3)}

Common in the dry open forest on the Cooloola sand mass and Fraser Island, also occasionally taken in adjacent rainforest. Trapped with human excrement baits.

\section{Comments}

This species is close to $O$. cuniculus Macleay and $O$. dandalu Matthews. It can be easily distinguished by its blue-green colour as opposed to green or coppery green. The pronotal process of the male is smoothly curved to the base and the apex is wider, truncate or feebly bifurcate in comparison with the more sinuate, narrower condition in the other two species. The anterior angles are quite protruding and rounded, this caused by the lateral pronotal margin being depressed just before the corner. This sinuate appearance is also found in the female of $O$. beelarong, which also has a more rugose clypeus than the other two species.

Onthophagus gurburra, sp. nov.

(Figs 33-35)

\section{Material Examined}

Holotype. Ơ, Queensland: $11^{\circ} 40^{\prime} \mathrm{S} ., 142^{\circ} 50^{\prime}$ E., Captain Billy Creek, Cape York Peninsula, 913.vii.1975, G. B. Monteith, in QM, T10 890.

Paratypes. (185), Queensland: $190^{\circ}, 16 \%$, same data as holotype; $220^{\circ}, 15 \%$, Dividing Range, $15 \mathrm{~km}$ W. of Captain Billy Creek, Cape York Peninsula, 4-9.vii.1975, G. B. Monteith; 10 , Lockerbie, Cape York, 10-15.vi.1969, G. B. Monteith; 50*, 1\%, same data, 23-27.iv.1973, $10^{\circ}$, same data, 11.iv.1975, M. Walford-Huggins; 4o , 7९, same data, 7-12.iv.1977, R. I. Storey; $10^{\circ}, 11^{\circ} 28^{\prime}$ S., 
$142^{\circ} 25^{\prime}$ E., McDonnell Scrub, Cape York Peninsula, 13-14.vii.1975, G. B. Monteith; 1 ${ }^{*}$, 6\%, Iron Range, Cape York Peninsula, 28.iv-17.v.1968, G. Monteith; 1 ${ }^{\circ}$, same data, May 1968, G.M., 11 ơ, 8\%, same data, 15-21.iv.1977, R. I. Storey; 1\%, Mt Tozer Area, Iron Range, 29.iv-1.v.1973, G. B. Monteith; $80^{\circ}, 17 \%, 12^{\circ} 44^{\prime} \mathrm{S} ., 143^{\circ} 14^{\prime} \mathrm{E}$., $3 \mathrm{~km}$ ENE. of Mt Tozer, 1-4.vii.1986, T. Weir;

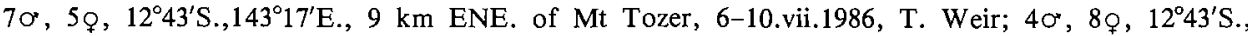
$143^{\circ} 16^{\prime} \mathrm{E}$., $7 \mathrm{~km}$ ENE. of Mt Tozer, 6.vii.1986, T. Weir; $20^{\circ}, 4 \%, 12^{\circ} 43^{\prime} \mathrm{S} ., 143^{\circ} 18^{\prime} \mathrm{E} ., 11 \mathrm{~km}$ ENE. of Mt Tozer, 12-16.vii.1986, T. Weir; 4\%, Gordon's Mine Area, Iron Range, 12-18.ii.1976, G. B. Monteith; 50*, 1\%, Leo Creek Rd, McIlwraith Range, 30 km NE. of Coen (c. $500 \mathrm{~m})$, 29.vi-4.vii. 1976, G. B. Monteith. Paratypes in: ANIC, AWHC, QDPIM, QM, QUE, SAMA.

\section{Description}

Black, pronotum and head with green, purple or coppery reflections, antennal clubs fulvous, pilosity pale. Total length $6 \cdot 3-9 \cdot 3 \mathrm{~mm}$.

\section{Male}

Head. Clypeal margin prolonged medially, reflexed, with tip rounded, rest of margin straight, expanded just before genal angles which are rounded. Clypeal suture with frontal section very fine, not carinate but complete. Vertex with a broad flattened lamina, lamina divided into two separate lobes by a ' $U$ ' shaped groove, each lobe ending in an erect rounded process along outer margin, about one-third length of lamina, inner margin with a small point ending about start of the outer process; armament reduced in minor male to condition of female. Eyes dorsally 8-10 facet rows in width, separated by $9-11$ eye widths, canthus complete. Surface with scattered minute punctures, clypeal punctures almost totally effaced, less so in minor male, nitid, glabrous. Labium emarginate.

Pronotum. Convex, with a ' $\mathrm{Y}$ ' shaped swelling between head lamina and a slight depression behind each laminal process; reduced to two tumescences in minor male. Anterior angles quadrate, apices rounded, very feebly prominent, lateral margin sinuate. Hind edge finely margined. Punctures minute, scattered over entire surface, very nitid, glabrous.

Elytra. Intervals flat to feebly convex, punctures sparse, minute, bases of all but 1 st and 5th intervals swollen, centre of 7 th also swollen. Long, pale, fine setae along length of last interval, continuing on to apex of other intervals. Striae very fine, effaced in centre, moderate punctures crenulating surface.

Legs. Fore tibiae slightly elongate.

Abdomen. Pygidium nitid, punctate over entire surface with medium punctures, fine long pilosity, not dense. Aedeagus as in Fig. 34.

\section{Female}

Clypeal margin not reflexed or expanded, surface strongly transversely rugose, clypeal suture carinate. Vertex with a pair of flattened points, a little closer to centre than eye, with a slight depression in front, very smooth, nitid, almost impunctate. Front of pronotum with a ' $V$ ' shaped swelling, flanked by a shallow depression on either side, pronotunı less convex. Fore tibiae normal. Otherwise like male.

\section{Distribution (Fig. 3)}

In wetter areas of the east coast of Cape York Peninsula, from Lockerbie to the McIlwraith Range. Trapped with human excrement baits in both open and closed forest.

\section{Comments}

This species is closely related to $O$. auritus Erichson and $O$. furcaticeps Masters. It can be separated by the cephalic armament of the male, each side of the lamina having a pair of processes (a tall outer one and a shorter inner one) whereas the other two species have a single process. The very nitid, almost impunctate frons of the female with a pair of elevated, flattened points is also distinctive. $O$. guburra has the most northern distribution of these three species. Specimens of $O$. furcaticeps listed by Matthews (1972) from Iron 
Range and located at QUE are $O$. gurburra. Thus, there is apparently no area of overlap between $O$. auritus, $O$. furcaticeps and $O$. gurburra.

\section{adelaidae group}

Onthophagus dinjerra, sp. nov.

(Figs 36-38)

\section{Material Examined}

Holotype. $\sigma^{\circ}$, South Australia: Ceduna, 14.viii.1972, H. F. Howden, in SAMA.

Paratypes. (101), South Australia: $170^{\circ}, 25 \%$, same data as holotype; $10^{\circ}, 1 \%, 2 \mathrm{~km} \mathrm{~W}$. of Poochera, 23.x.1977, J. Feehan; $10^{\circ}$, S. Aust. Western Australia: $190^{\circ}, 19 \%$, Glengarry Stn, $15 \mathrm{~km}$ E. of Geraldton, 3.x.1978, J. Matthiessen; $30^{\circ}, 3 \wp, 15 \mathrm{~km} \mathrm{E}$. of Geraldton, 12.ix.1978, J. RidsdillSmith; 1\%, $26 \mathrm{~km}$ NNE. of Geraldton, Oakajee district, 29.vii.1972, D. and N. McFarland; $1 \%$, $40 \mathrm{~km}$ S. of Geraldton, 29.vii.1972, E. G. Matthews; $10^{\circ}$, Geraldton, Sept. 1926, H. J. Carter; $1 \sigma^{\circ}, 11 \mathrm{~km}$ W. of Northampton, 29.x.1952, McIntosh and Calaby; 1\%, Kojarina, Oct. 1926, H. J.

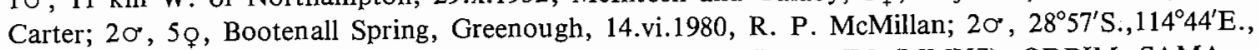
Greenough, 26.viii.1978, R. P. McMillan. Paratypes in: ANIC, ANIC (MMUS), QDPIM, SAMA.

\section{Description}

Black, head and pronotum often with greenish or bronze reflections, especially in the males, antennal clubs fuscous. Total length $4 \cdot 5-6 \cdot 5 \mathrm{~mm}$

\section{Male}

Head. Clypeal margin medially strongly bidentate, teeth acute, rest of margin a little expanded before clypeal suture, genal angles rounded, about halfway on genal margins, slightly convex behind angles. Clypeal suture of major male with frontal section completely effaced, genal sections finely carinate; intermediate and minor male with an indication of frontal section present as a straight line between genal sections, not carinate. Frons of major male with a pair of erect, slender, divergent horns which are recurved and bent back apically, arising near to eyes and with surface flat between them; intermediate male with a pair of short, parallel horns in this position; minor male with a weak carina raised into angles near eyes. Eyes dorsally 5-6 facet rows in width, separated by about 15 eye widths, canthus incomplete. Major male with surface of clypeus smooth, nitid, finely punctate, frons smooth, nitid, finely shagreened between and behind horns, genae coarsely punctate, shagreened; intermediate male with punctures on clypeus and frons coarser than in major male; minor male with very coarse punctures on clypeus and shagreening of frons more distinct. Clypeus with a fringe of long erect setae around edge and a few long, erect setae in basal angles near clypeal suture. Labium shallowly emarginate.

Pronotum. Strongly convex in major male with anterior declivity flattened, median area of declivity slightly more raised than areas behind horns; less strongly convex in intermediate and minor males and anterior declivity not evident. Anterior angles quadrate, the apices subangular. Hind edge distinctly margined. Surface moderately punctate with medium sized, shallow, round punctures separated by about two diameters on the disc, somewhat smaller and sparser on anterior declivity, each puncture with a seta, in major male long and erect on the anterior declivity and sides, short and recurved on the disc; shorter on anterior areas and sides in intermediate and minor males. Surface between punctures shagreened, smooth, sericeous.

Elytra. Intervals slightly convex, shagreened, each with two rows of small setae, one row on sutural interval and 3-4 rows on last interval. Striae superficial, geminate, nitid, with small shallow punctures.

Legs. Fore tibiae in major male slightly elongate, straight, inner angle produced into a small tooth, without apical tuft of long setae; intermediate and minor male with fore tibiae not elongate, apical inner tooth shorter. 
Abdomen. Pygidium shagreened, with small scattered punctures, each bearing a small seta. Aedeagus as in Fig. 37.

\section{Female}

Clypeal margin with teeth less prominent, surface more densely punctate and rugose. Clypeal suture with frontal section present, straight, carinate, meeting genal sections at an angle, genal areas not shagreened. Frons more densely punctate, partly shagreened or not, with a low carina bent back in the middle and raised into angles near the eyes. Pronotum much less convex, more densely punctate, nitid on the disc in some specimens and with setae along front and sides shorter; anterior angles ranging from acute to subquadrate. Elytra with middle of intervals nitid in some specimens. Fore tibiae unmodified. Otherwise like male.

\section{Distribution (Fig. 2)}

Known from Ceduna and Poochera in South Australia and the Geraldton area of Western Australia; active in winter and spring from July to October. The specimens from Glengarry Station, Western Australia were taken in cow dung baited pitfall traps in open areas during the day, while those from Greenough came from sand dunes.

\section{Comments}

Females of this species vary in the surface structure of the pronotum and elytra. The pronotum ranges from completely shagreened and alutaceous to nitid on the disc, as does the middle of the elytral intervals, in both the Ceduna and Geraldton populations. The two male specimens from near Northampton (McIntosh and Calaby) and Geraldton (Carter) were mentioned by Matthews (1972) under $O$. duboulayi Waterhouse as having acute anterior angles to the pronotum, while the single female from Kojarina (Carter) was listed by him (as Kojarena) under $O$. jubatus Harold. $O$. dinjerra is most closely related to $O$. duboulayi but it and the following species can be separated from $O$. duboulayi and $O$. jubatus by the following modifications to Matthews' (1972) key to the species of the adelaidae group.

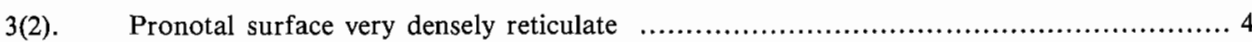

Punctures of pronotal surface more widely spaced $\ldots \ldots \ldots \ldots \ldots \ldots \ldots \ldots \ldots \ldots \ldots \ldots \ldots . .5$

4(3). Male with a pair of divergent horns on frons; head surface rugose; head and pronotum densely setose; s.e. S.A., N.S.W., s. Qld ............................ O. adelaidae Hope

Male with a single bifurcate horn on frons; head rugose only on genae; head and pronotum with only a few setae; s. Qld O. phoenicocerus Lea

5(3). Head margin strongly notched at genal suture; disc of pronotum with impressed, ocellate punctures, each bearing a seta; punctures on anterior declivity and sides of pronotum with a raised anterior edge; (male with frontal section of clypeal suture effaced and a pair of divergent horns on frons; female frons with a short, elevated, recurved carina); W.A.

O. godarra, sp. nov.

Head margin not strongly notched at genal suture; disc of pronotum with punctures not ocellate but still bearing setae (often worn off); punctures on anterior declivity similar to those on disc, not with a sharp anterior edge

5a(5). Surfaces nitid; male with frontoclypeal suture at least partly carinate; major male with head horns short, vertical; female with a pair of sharp, oblique ridges on frons, covered with short, erect setae; S.A., n. W.A., N.S.W. ......................... O. jubatus Harold

Surfaces shagreened, matt or sericeous often with bronze reflections, sometimes nitid on disc of pronotum and middle of some elytral intervals; male with frontoclypeal suture completely or partly effaced, not carinate; major male with head horns long, projecting above level of pronotum; female with either a straight, sharp carina raised laterally into points or a low, blunt carina bent posteriorly in the middle and without setae ..... 5b

$5 \mathrm{~b}(5 \mathrm{a})$. Pronotum with anterior angles broadly rounded; frons with setae; male with punctures around base of head horns larger than those between horns; female frons with a sharp transverse carina raised laterally into points; s. W.A. ................... O. duboulayi Waterhouse

Pronotum with anterior angle angulate; frons without setae; male with punctures around base of head horns same size as those between horns; female frons with a low, blunt carina bent back in the middle; S.A., W.A. O. dinjerra, sp. nov. 
Onthophagus godarra, sp. nov.

(Figs 39-41)

\section{Material Examined}

Holotype. $\sigma^{\circ}$, Western Australia: $30 \mathrm{~km} \mathrm{N.} \mathrm{of} \mathrm{Murchison} \mathrm{R.,} \mathrm{30.viii.1972,} \mathrm{E.} \mathrm{G.} \mathrm{Matthews,} \mathrm{in}$ SAMA.

Paratypes. (67), Western Australia: 4०, 5\%, same data as holotype; $1 \%, 80 \mathrm{~km} \mathrm{~N}$. of Carnarvon, 30.vii.1972, E. G. Matthews; $2 \varnothing, 120 \mathrm{~km} \mathrm{~N}$. of Carnarvon, 1.viii.1972, E. G. Matthews; $10^{\circ}, 1 \%$, Peron Peninsula near Nanga, 4.viii.1972, E. G. Matthews; $1 \odot$, same data, 2-3.viii.1972, H. Howden; $8{ }^{\circ}, 220,30-50 \mathrm{~km} \mathrm{~N}$. of Carnarvon on Blow Holes Rd, 20-21.vii.1978, H. and A. Howden; 1\%, 5-10 km S. of Carnarvon, 5-6.viii.1978, H. and A. Howden; $1 \sigma^{\circ}, 3 \%, 71 \mathrm{~km} \mathrm{N.} \mathrm{of} \mathrm{Carnarvon,}$ 22.vii.1978, H. and A. Howden; 5०, 1 , Blow Holes Rd, Carnarvon, 3.ix.1978, K. and E. Carnaby; 1 , Coral Bay, 2-4.viii.1978, K. and E. Carnaby; 1\%, Kalbarri, 18.vii.1978, K. and E. Carnaby; 1 , $12 \mathrm{~km} \mathrm{~S}$. of Yuna/Kalbarri Junction, 10.viii.1978, H. and A. Howden; 5o, 4\%, $5 \mathrm{~km} \mathrm{~N}$. of Wooramel R., 19.vii.1978, H. and A. Howden. Paratypes in: ANIC, HFHC, QDPIM, SAMA.

\section{Description}

Black, antennal clubs fuscous. Total length $4 \cdot 5-6 \cdot 7 \mathrm{~mm}$.
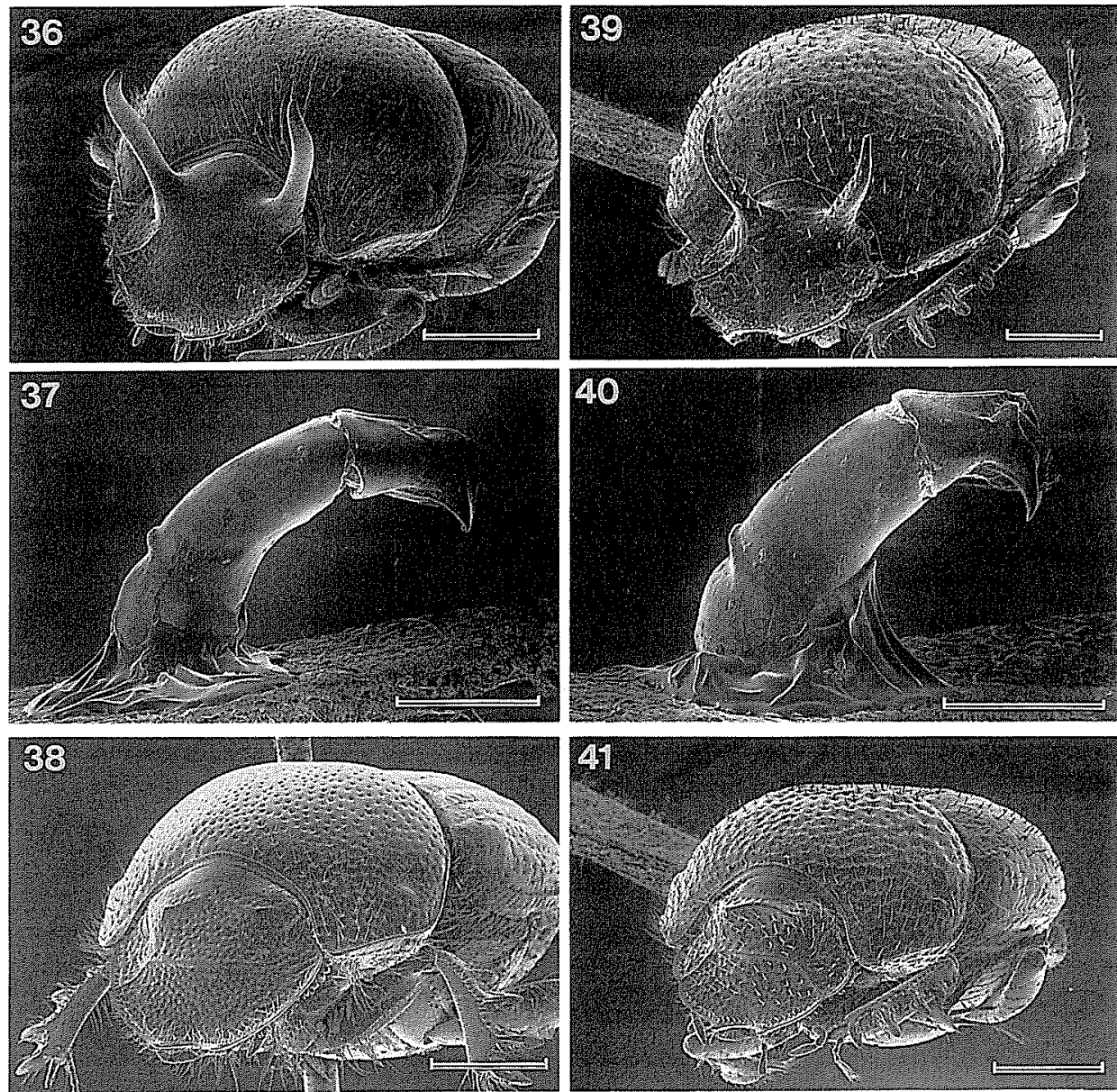

Figs 36-38. Onthophagus dinjerra: 36, head and pronotum, male; 37, aedeagus; 38 , head and pronotum, female.

Figs 39-41. Onthophagus godarra: 39, head and pronotum, male; 40, aedeagus; 41, head and pronotum, female.

Scale lines: $36,38,39,41,1 \cdot 0 \mathrm{~mm} ; 37,40,0 \cdot 5 \mathrm{~mm}$. 
Male

Head. Clypeal margin very deeply excised, the excision flanked by a pair of prominent, acute teeth, rounded at the tip, rest of margin a little expanded, forming a distinct angulate notch at junction with genal section of clypeal suture, genal angles not prominent. Clypeal suture with frontal section completely effaced, genal sections finely carinate. Frons of major male with a pair of divergent horns arising near to eyes, slightly recurved and incurved at tips which are slightly higher than disc of the pronotum, with surface flat between; intermediate male with horns shorter, minor male with horns reduced to sharp points joined by a sharp carina. Eyes dorsally 5-6 facet rows in width, separated by $12-14$ eye widths, canthus incomplete. Middle of clypeus and frons, moderately punctate, the punctures extending up head horns almost to tips, and coarsely punctate on sides of clypeus and genal areas, each puncture bearing an erect seta, smooth, nitid. Clypeus with a fringe of erect setae around edge. Labium shallowly emarginate.

Pronotum. Strongly convex in major male with disc grading smoothly into anterior declivity which is slightly flattened; less strongly convex in intermediate male and anterior declivity shorter; minor male evenly convex. Anterior angles quadrate, apices angulate and margins slightly concave immediately behind. Hind edge distinctly margined. Surface moderately punctate with medium sized punctures separated by 1-2 diameters, punctures on disc ocellate and impressed, those on anterior declivity and sides reniform with raised anterior margin, each puncture bearing on erect seta, longer on anterior declivity than on disc, surface between punctures nitid or subnitid, finely shagreened anteriorly and at sides and finely shagreened or smooth on disc.

Elytra. Intervals slightly convex, with uneven surface, subnitid, entirely shagreened or with smooth middle, each with two rows of small erect setae, one row on sutural interval and scattered only on humeral area of last interval. Striae superficial, geminate, nitid, with small round punctures.

Legs. Fore tibiae slightly elongate, straight, inner apical angle quadrate, without apical tuft of long setae.

Abdomen. Pygidium nitid or subnitid, smooth, shagreened along base and sides or may be all shagreened, with shallow, scattered ocellate punctures, each bearing a short seta. Aedeagus as in Fig. 40.

\section{Female}

Head surface more densely and coarsely punctate, middle of clypeus and frons same as rest of surface. Clypeal margin less deeply excised; clypeal suture with frontal section present, straight, carinate, meeting genal sections at an angle, higher in middle than at sides. Frons with short, elevated, transverse carina, angulate laterally and recurved medially. Pronotum much less convex, without defined anterior declivity, ocellate punctures of disc more deeply impressed. Fore tibiae unmodified. Otherwise like male.

\section{Distribution (Fig. 2)}

Known from the east coast of Western Australia in an area extending from $120 \mathrm{~km}$ north of Carnarvon south to the Murchison River. Collected from July to September.

\section{Comments}

This species is closest to $O$. jubatus Harold but may be separated from it and other species in the adelaidae group by the characters given in the modified key under the preceding species. 


\section{perpilosus group \\ Onthophagus arkoola, sp. nov.}

(Figs 42-44)

\section{Material Examined}

Holotype. O', Queensland: $5 \mathrm{~km} \mathrm{E.} \mathrm{of} \mathrm{Camooweal,} \mathrm{19.xii.1971,} \mathrm{P.} \mathrm{Ferrar,} \mathrm{in} \mathrm{ANIC,} \mathrm{ANIC}$ No. 97.

Paratypes. (17), Queensland: $30^{\circ}, 7 \%$, same data as holotype; $10^{\circ}, 1 \%$, Undilla Stn, via Camooweal,

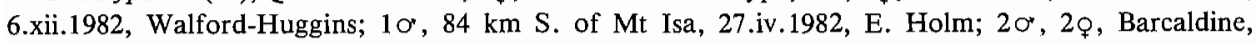
$1978,{ }^{\circ}$ R. Cheffins. Paratypes in: ANIC, AWHC, QDPIM.

\section{Description}

Black, with slight purplish or greenish reflections, elytra with yellowish-white maculations as follows: apices of intervals 3, 4, 5 and 6; base of intervals 3 , and 5 to one-third of length; base of 2,4 and 6 to half of length; shoulder only of 7 , and 8 , antennal clubs fuscous, almost black. Total length $5 \cdot 7-7 \cdot 2 \mathrm{~mm}$.

Male

Head. Clypeal margin medially bilobate, reflexed, lobes rounded, rest of margin expanded before genae, genae prominent, rounded. Clypeal suture complete, frontal section carinate, genal sections less so, frontal section straight, strongly angled to genal sections. Low fold across vertex, produced as an acute point behind each eye. Eyes dorsally 7-8 facet rows in width, separated by 10-11 eye widths, canthus incomplete. Numerous large punctures on clypeus, frons and genae, surface between punctures smooth, nitid. Medium-length setae on clypeus and frons near eyes, fringe of medium, close set setae near clypeal margin. Labium bilobate, shallowly excised.

Pronotum. Convex, small depression behind head, front edge carinate with centre drawn out into a point, hind edge also carinate but constant in height, these two carina joined across middle by a short low carina in one specimen, midline of disc feebly impressed. Anterior angles quadrate, apices rounded. Hind edge margined. Small to medium, scattered, irregular punctures over entire surface, reduced towards hind edge, long setae on sides and front, these in large ocellate punctures, absent on central portion, nitid

Elytra. Intervals flat to feebly convex, shagreened, scattered small punctures. Setae on entire length of intervals 7 , and 8 , variable on 2,4 and 6 , one or two rows. Striae shallow, geminate, with numerous medium punctures.

Legs. Fore tibiae elongate, inner edge drawn out into a short tooth, as long as spur, outer teeth reduced in size.

Abdomen. Pygidium shagreened, moderate punctures each with medium-length erect seta. Aedeagus as in Fig. 43.

\section{Female}

Clypeus longer, median lobes more acute, genae less prominent, fold on vertex curved forward, not drawn out into points, centre section more elevated. Pronotum less convex, scupturing as in male but less prominent. Fore tibiae unmodifed. Otherwise like male.

\section{Distribution (Fig. 3)}

The known localities are in inland Queensland, in areas with $200-400 \mathrm{~mm}$ annual rainfall. Collected in cow and horse dung.

\section{Comments}

This species is the most distinctive member of Matthews' (1972) perpilosus species group, easily recognised by the yellowish-white maculations on the elytra. Like its relatives, it is a dry inland species, being recorded in the driest conditions known for any member of this species group. 


\section{mutatus group}

Onthophagus yaran, sp. nov.

(Figs 45-47)

\section{Material Examined}

Holotype. ơ, Queensland: Watsonville, via Herberton, 5-12.xii.1976, R. I. Storey, in QM, T10 897.

Paratypes. (209), Queensland: 22\%, 18\%, same data as holotype, 1\%, same data, 10-12.ii.1980; $10,1 \%$, Hughenden Rd, $75 \mathrm{~km} \mathrm{SW}$. of Mt Garnet, 25.i.1972, J. G. Brooks; $3 \sigma, 27 \mathrm{~km} \mathrm{E.} \mathrm{of}$ Forsayth, 20-21.xi.1976, R. I. Storey; 13o, 12\%, same data, 24.xii.1977; 9o, 6\%, $40 \mathrm{~km}$ W. of Georgetown, 9.i.1978, R. I. Storey and I. Titmarsh; 4o , 16q, Routh Ck, via Georgetown, 8.i.1980, R. I. Storey; 90, 18\%, Einasleigh R., via Mt Surprise, 6-7.i.1980, R. I. Storey; 1\%, Bakerville, 15.vii.1970, J. H. Barrett; 3o, 1\%, same data, 30.xii.1969, J. D. Brown; 1\%, same data, 10.ii.1970, J. D. Brown; 4ᄋ, $12 \mathrm{~km} \mathrm{W.} \mathrm{of} \mathrm{Herberton,} \mathrm{29-30.xii.1978,} \mathrm{R.} \mathrm{I.} \mathrm{Storey;} \mathrm{1o,} \mathrm{Chillagoe,} \mathrm{29.i.1984,}$ R. I. Storey; 1 , Petford, 27-29.i.1978, R. I. Storey; 1 , $17^{\circ} 11^{\prime} \mathrm{S} ., 145^{\circ} 02^{\prime}$ E., Eureka Ck, $9 \mathrm{~km} \mathrm{SW}$. of Dimbulah, 20.xi.1981, J. Balderson; 1 $\sigma$, 7\%, Station Ck, $17 \mathrm{~km} \mathrm{N.} \mathrm{of} \mathrm{Mt} \mathrm{Molloy,} \mathrm{30.xii.1969,}$ J. G. Brooks; $20^{*}, 4 \%$, same data, 2.i.1970, 16॰, 16\%, same data, 2.ii.1972, 2q, same data, 28.vi. 1970, $1 \%$, same data, 21.xii.1970, 2\%, same data, 9.i.1970, A. and M. Walford-Huggins; 4o, same data, 2.ii.1970, R. E. Parrott; lơ, same data, 11.ii.1970, R. E. Parrott; 2ᄋ, same data, 9.ii.1978,
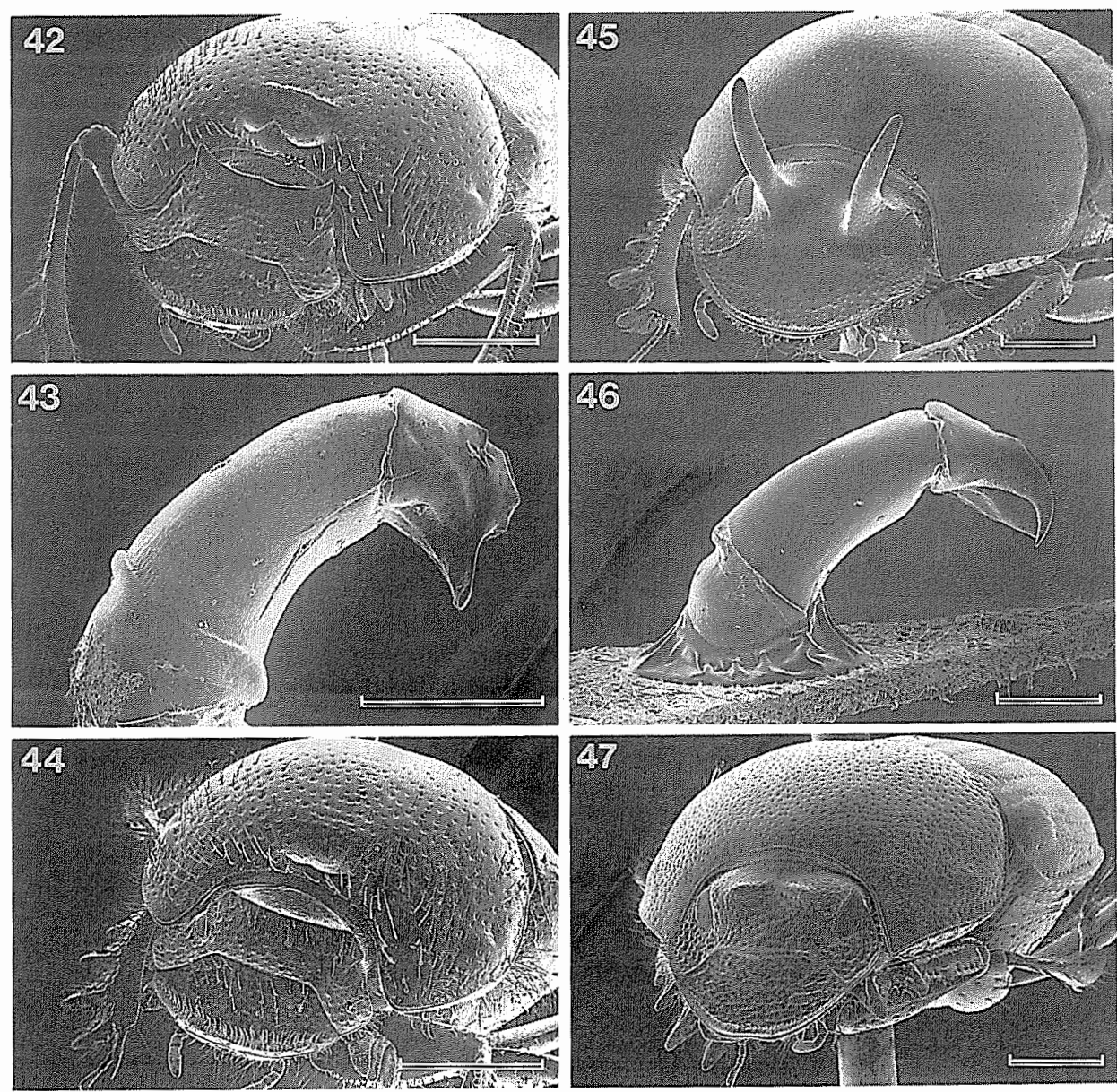

Figs 42-44. Onthophagus arkoola: 42, head and pronotum, male; 43, aedeagus; 44, head and pronotum, female.

Figs 45-47. Onthophagus yaran: 45, head and pronotum, male; 46, aedeagus; 47, head and pronotum, female.

Scale lines: $42,44,45,47,1 \cdot 0 \mathrm{~mm} ; 43,46,0.5 \mathrm{~mm}$. 
R. I. Storey and N. Gough; $1 \sigma^{*}, 1 \%, 16^{\circ} 33^{\prime} \mathrm{S} ., 145^{\circ} 12^{\prime} \mathrm{E}$, Mary Ck, 4.xii.1968, Britton and Misko; $10^{*}, 1 \%$, Mitchell R., via Mt Carbine, 20.i.1984, R. I. Storey; $1 \sigma^{*}, 16^{\circ} 19^{\prime} \mathrm{S} ., 145^{\circ} 24^{\prime} \mathrm{E}$., $12 \mathrm{~km}$ SE. of Daintree, 22.xi.1981, J. Balderson. Paratypes in: ANIC, AWHC, BM(NH), HFHC, QDPIM, QM, QUE, SAMA.

\section{Description}

Black, antennal clubs fuscous or black. Total length $5 \cdot 5-8 \mathrm{~mm}$.

\section{Male}

Head. Clypeal margin medially almost straight, rest of margin evenly rounded, genal angles rounded. Frontal section of clypeal suture represented only by slight swelling, genal sections distinct, oblique. Frons of major male with a pair of long erect usually conical sometimes transverse horns next to the eyes, about length of head, slightly divergent and inclined backwards towards tip; reduced to small points in minor male. Eyes dorsally 8-9 facet rows in width, separated by $10-12$ eye widths, canthus complete. Surface with moderate punctures, separated by 1-2 widths, sparser on frons, nitid, glabrous. Labium excised about one-third of way to base.

Pronotum. Convex, anterior face slightly flattened adjacent to front margin, especially behind head, otherwise unsculptured. Anterior angles quadrate. Hind edge finely margined. Surface moderately densely punctate with medium sized punctures, a bit finer on centre of disc, separated by 1-2 diameters, surface between matt to alutaceous with microtrichia.

Elytra. Intervals feebly convex, finely punctate with microtrichia, matt except humeri which are nitid. Striae feebly impressed, geminate, punctate with medium punctures.

Legs. Fore tibiae slightly elongate.

Abdomen. Pygidium large, matt, with numerous fine punctures, most with short recurved setae. Sternites foreshortened, first five about half length of 6 th in centre.

Ventral surface. Centre of metasternum with a large patch of short recurved, flattened setae. Aedeagus as in Fig. 46.

\section{Female}

Clypeal margin emarginate, slightly bilobate, frontal section of clypeal suture carinate, surface transversely rugose. Frons with a short, curved, low carina, about half the length of the distance between eyes in length, close to back of head, slightly raised at ends. Pronotum less convex, not flattened along anterior margin, alutaceous to nitid. Elytra alutaceous to nitid. Fore tibiae not at all elongate. Apex of pygidium nitid, sternites not foreshortened in centre. Metasternum without patch of modified setae. Otherwise like male.

\section{Distribution (Fig. 4)}

$O$. yaran replaces $O$. jangga Matthews in the area west of and immediately adjacent to the Atherton Tableland, though a region of overlap could occur in the Mt Carbine area. Trapped with human excrement baits and taken at carrion and light.

\section{Comments}

Although the foreshortened abdominal sternites of the male are similar to those of members of the planicollis group and may cause problems in Matthews' (1972) key to species groups, all other characters of this species are consistent with those of the mutatus group, and $O$. yaran, would appear to be quite close to $O$. jangga, to which it is very similar in size and build. The unusual character of a group of modifed setae on the metasternum of the male is also found in that species. Distribution, long horns in the male and the matt integument should allow separation of $O$. yaran from related species. 


\section{posticus group}

Onthophagus yackatoon, sp. nov.

(Figs 48-50)

\section{Material Examined}

Holotype. O $^{*}$ New South Wales: Oakwood, 8.viii.1957, T. V. Bourke, in NSWDA.

Paratypes. (22), New South Wales: $2 \sigma^{\circ}, 3 \%$, same data as holotype; $10^{*}$, Sinclair's Lookout (Glen Innes-Inverell Rd), 6.xii.1965, G. A. Yapp; 3o*, Graman, 10.xii.1959, T. V. Bourke; 10*, same data, 7.ix.1960, $1 \sigma^{\circ}$, same data, 8.xii.1960, 1\%, same data, 10.xii.1960, 30, 4\%, same data, 3.iv.1961, 1o , same data, 28.xi.1961, 1\%, same data, 26.viii.1959, P. G. Regan; 1 $\%$, same data, 29.vii.1961, P. G. Regan. Paratypes in: ANIC, NSWDA, QDPIM.

\section{Description}

Black with slight purplish reflections, antennal clubs black. Total length $4 \cdot 8-5 \cdot 8 \mathrm{~mm}$.

\section{Male}

Head. Clypeal margin bilobate, evenly rounded to genal angles, genae rounded. Frontal section of clypeal suture effaced, slight tumescence in centre, genal sections strong, frons
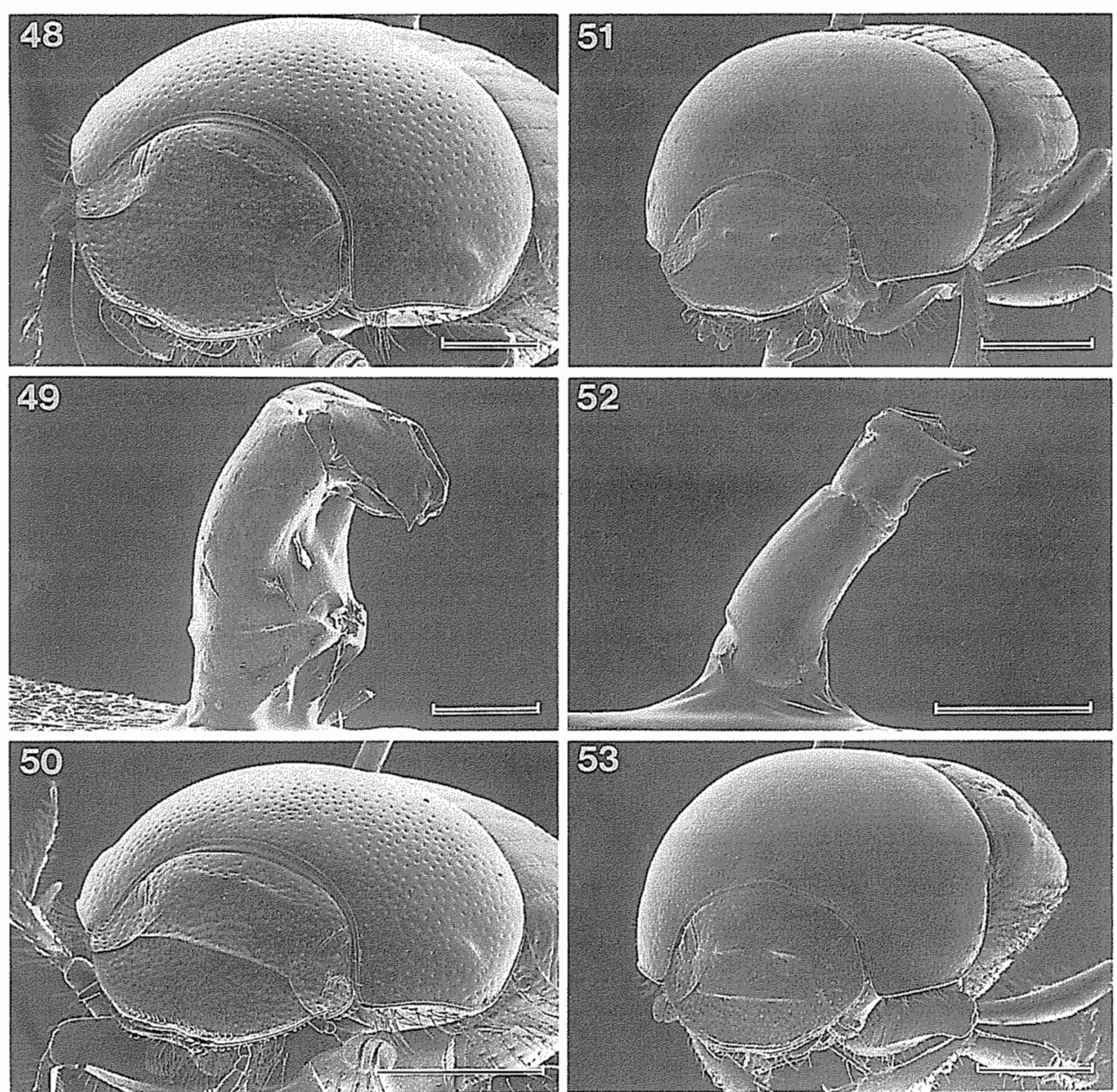

Figs 48-50. Onthophagus yackatoon: 48, head and pronotum, male; 49, aedeagus; 50, head and pronotum, female.

Figs 51-53. Onthophagus bindaree: 51, head and pronotum, male; 52, aedeagus; 53, head and pronotum, female.

Scale lines: $50,51,53,1 \cdot 0 \mathrm{~mm} ; 48,49,52,0.5 \mathrm{~mm}$. 
with carina in middle about half distance between eyes in length, slight depression in front. Eyes dorsally 5-6 facet rows in width, separated by 14-16 eye widths, canthus incomplete. Surface moderately punctate, clypeus feebly rugose, nitid, glabrous except for a fringe of close-set short setae near apical border of clypeus. Labium emarginate.

Pronotum. Feebly convex, unsculptured. Anterior angles quadrate, lateral margin slightly sinuate behind, apices acute. Hind edge not margined. Surface moderately punctate with medium punctures, nitid, glabrous.

Elytra. Intervals feebly convex, slightly shagreened, with scattered fine punctures, apex of 2 nd interval flattened. Sparse recurved setae on full length of last interval and apices of other intervals, continuing further on to disc on odd numbered intervals. Striae geminate, moderately impressed with medium punctures.

Legs. Fore tibiae elongate with apical tuft of setae, about twice length of spur.

Abdomen. Pygidium shagreened, scattered small punctures each with a recurved seta except along midline. Aedeagus as in Fig. 49.

\section{Female}

Lobes of clypeus slightly more protruding, frontal section of clypeal suture straight, carinate. Frontal carina less developed. Elytra very nitid. Fore tibiae unmodified. Otherwise like male.

\section{Distribution (Fig. 4)}

Known from localities near Inverell in northern New South Wales, on the western side of the Great Dividing Range.

\section{Comments}

This small species is apparently a member of Matthews' (1972) posticus group, yet does not seem to be closely related to any other member of that group. It is more extensively setose, setae being found on the last interval, apices and encroaching onto the disc of the elytra on odd numbered intervals. The setae are also larger but sparser. Like $O$. posticus Erichson, it has a distinct frontal carina in both sexes, but its smaller size and black coloration will easily distinguish $O$. yackatoon from that species.

\section{rubescens group}

Onthophagus bundara, sp. nov.

(Figs 64-67)

\section{Material Examined}

Holotype. O*, Queensland: Hugh Nelson Ra, $21 \mathrm{~km}$ S. of Atherton, 13.iii-i.v.1984, Storey and Brown, in QM, T10 888.

Paratypes. (118), Queensland: 550, 32\%, same data as holotype, 12.x-5.xi.1983, 5.xi-1.xii.1983, 1.xii.1983-9.i.1984, 9.i-10.ii.1984, 10.ii-13.iii.1984, 13.iii-1.v.1984, 1.v-21.vi.1984, 21.vi-26.vii.1984,

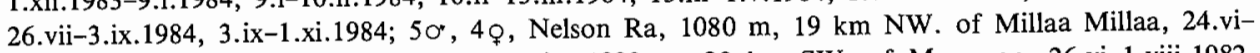
2.viii.1982, S. and J. Peck; $10^{\circ}$, Mt Lewis, $1000 \mathrm{~m}, 20 \mathrm{~km} \mathrm{SW}$. of Mossman, 26.vi-1.viii.1982,

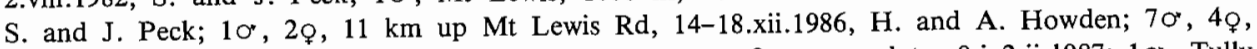
same data, 26.xii.1986-8.i.1987, Howden and Storey; 40*, 2ᄋ, same data, 8.i-2.ii.1987; $10^{\circ}$, Tully Falls S.F., $18 \mathrm{~km}$ SSW. of Ravenshoe, 7.xii.1987-7.i.1988, Storey and Dickinson. Paratypes in: ANIC, HFHC, QDPIM, QM.

\section{Description}

Rufopiceous, disc of pronotum and elytra a bit darker in some specimens, antennal clubs flavous. Total length $3 \cdot 2-4 \cdot 0 \mathrm{~mm}$. 
Male

Head. Clypeal margin bidentate, teeth rounded, rest of margin feebly curved to genal angles which are subangulate. Clypeal suture with frontal section effaced, slight swelling in centre. Frons with pair of slight swellings midway between centre and each eye. Eyes dorsally about eight facet rows in width, separated by about nine eye widths, canthus incomplete. Surface moderately evenly punctate with fine punctures, finely transversely rugose near outer margin of clypeus, glabrous, nitid. Labium shallowly excised.

Pronotum. Moderately convex, unsculptured. Anterior angles subquadrate, apices angulate. Hind edge finely margined. Surface moderately punctate with fine punctures separated by about three diameters, glabrous, nitid, smooth.

Elytra. Intervals very flat, smooth nitid with numerous fine punctures, glabrous. Striae fine, shallow, simple, with fine punctures.

Legs. Fore and hind tibiae slightly elongate, spur of fore tibia truncate.

Abdomen. Pygidium feebly convex, almost flat, with scattered medium punctures, a few short, recumbent setae near outer edge.

Ventral surface. Mesosternum with a prominent, slightly bifurcate protuberance between the middle pair of legs in major male, up to about one-quarter the thickness of the beetle, with a shallow depression at base just in front of hind legs; reduced or unmodified in minor males. Aedeagus as in Fig. 65.

\section{Female}

Clypeal suture complete, clypeal surface more rugose, fore and hind tibiae and mesosternum unmodified. Otherwise like male.

\section{Distribution (Fig. 3)}

This unusual species appears to be limited to closed forest at about $1000 \mathrm{~m}$ on the Hugh Nelson Range, south of Atherton and at Mt Lewis on the northern part of the Atherton Tableland and a bit lower $(730 \mathrm{~m})$ at Tully Falls; collected with both dung baited and flight intercept/trough traps. It was taken at every emptying of intercept traps run at two sites at the Hugh Nelson Range between 12.x.1983 and 1.xi.1984 (emptied at about five weekly intervals).

\section{Comments}

O. bundara runs to O. tuckonie Matthews/O. yarrumba Storey in Storey's (1977) key to species of the rubescens group, and is closely related to these species. It differs from them in the hind tibae being only slightly elongate in the male and the presence in major males of a mesosternal tubercle. Like $O$. tuckonie, the clypeal carina is complete in the female, the two species being inseparable in this sex. $O$. bundara can be easily separated from other small brown Onthophagus species at the type locality (O. waminda Matthews, $O$. wilgi Matthews and $O$. yungaburra Matthews) by the lack of setae on the last elytral interval.

Onthophagus bindaree, sp. nov.

(Figs 51-53)

Material Examined

Holotype. $\sigma^{*}$, Northern Territory: $16^{\circ} 47^{\prime}$ S., $135^{\circ} 45^{\prime}$ E., McArthur R., $14 \mathrm{~km} \mathrm{SW}$. of Cape Crawford, 11.iv.1976, J. E. Feehan, in ANIC, ANIC No. 98.

Paratypes. (11), Northern Territory: $10^{\circ}, 3 \%$, same data, as holotype; $1 \%$, Port Darwin; $1 \%$, Darwin. Western Australia: 1 $\sigma^{\circ}, 1 \%$, NW. Aust.; $1 \sigma^{\circ}, 1 \%, 15^{\circ} 38^{\prime} \mathrm{S} ., 125^{\circ} 15^{\prime} \mathrm{E} ., 4 \mathrm{~km}$ W. of King Cascade (CALM Site 28/3), 12-16.vi.1988, T. A. Weir; $1 \sigma^{\circ}, 15^{\circ} 25^{\prime} \mathrm{S} ., 125^{\circ} 15^{\prime} \mathrm{E}$., Augustus Is (CALM Site 26/1), 11-16.vi.1988, I. D. Naumann. Paratypes in: ANIC, ANIC(MMUS), QDPIM. 


\section{Description}

Black with faint iridescent tinge, except sides of pronotum which are rufous one-third to halfway to centre of disc and apex of elytra which are also rufous, antennal clubs fuscous. Total length $4 \cdot 5-5 \cdot 5 \mathrm{~mm}$.

\section{Male}

Head. Clypeal margin medially feeble, obtusely bidentate, rest of margin almost straight to genae which are obtusely angulate. Clypeal suture with frontal section effaced, genal sections present. Frons with a pair of low tumescences, distance between about equal to distance of each to eye, placed just behind position of clypeal suture, joined by a low carina in some individuals, disc of frons slightly depressed behind to back of head. Eyes narrow dorsally, about five facet rows in width, separated by about 14 eye widths, canthus incomplete. Surface with scattered medium punctures, separated by 1-2 diameters, very fine on centre of clypeus, glabrous, nitid. Labium excised about one-third of way to base.

Pronotum. Strongly convex, with slight anterior medial depression on front face. Anterior angles quadrate. Hind edge finely margined. Scattered medium punctures over entire surface, separated by 1-3 diameters, glabrous, nitid.

Elytra. Intervals flat, smooth, nitid, punctures sparse, fine, glabrous. Striae fine, simple, with small shallow punctures.

Legs. Forelegs unmodified.

Abdomen. Pygidium slightly convex,.smooth, nitid, with moderate punctures, separated by 1-2 diameters, most with short, recumbent setae. Aedeagus as in Fig. 52.

\section{Female}

Clypeus finely rugose, clypeal suture with frontal section carinate, straight, tumescences on frons replaced by a carinate suture, effaced in middle and before eyes. Pronotum not quite as convex, anterior medial depression less pronounced. Otherwise like male.

\section{Distribution (Fig. 1)}

Known from the type locality, the Darwin area and northern Western Australia. Trapped with human excrement bait in closed forest.

\section{Comments}

$O$. bindaree is closely related to $O$. manya Matthews, to which it will run in Storey's (1977) key to the rubescens group, and $O$. terrara Storey. It can be separated from them by the cephalic armament in both sexes (two small tumescences in the male and a medially interrupted frontal carina in the female) and by its distribution. The few available specimens of this species are variable, those from Western Australia differing from those from the Northern Territory by having the pronotum more coarsely punctate in the female and the cephalic tumescences joined by a low carina in the male. However, the aedeagi of the available males are identical and it is felt by the authors that only one species is involved.

\section{Onthophagus trawalla, sp. nov.}

(Figs 54-56)

\section{Material Examined}

Holotype. or, Queensland: $12^{\circ} 44^{\prime} \mathrm{S} ., 143^{\circ} 14^{\prime} \mathrm{E}$., $3 \mathrm{~km}$ ENE. of Mt Tozer, 1-4.vii.1986, T. Weir in ANIC, ANIC No. 99.

Paratypes. (4), Queensland: $10^{*}, 2 \wp$, same data as holotype; $10^{*}$, West Claudie R., Iron Range, 29-30.ix.1974, G. B. Monteith. Paratypes in: ANIC, QDPIM, QM.

\section{Description}

Black, very faint cupreous reflections, antennal clubs fulvous. Total length $3 \cdot 8-4 \cdot 4 \mathrm{~mm}$. 


\section{Male}

Head. Clypeal margin emarginate, feebly bidentate, teeth rounded, rest of margin almost straight to genal angles which are rounded. Clypeal suture with frontal section effaced, genal sections present but not carinate. Frons unsculptured. Eyes narrow dorsally, about five facet rows in width, separated by about 16 eye widths, canthus imcomplete. Surface with scattered fine punctures, a bit larger along frontal margin of clypeus, glabrous, nitid. Labium shallowly excised.

Pronotum. Slightly convex, unsculptured. Anterior angles subquadrate. Hind edge margined. Surface nitid, smooth with scattered fine punctures, separated by $2-4$ diameters, usually two or three short setae along middle of lateral margin.

Elytra. Intervals almost flat, smooth, nitid with a few fine punctures, glabrous except for two or three short recumbent setae near base of last interval. Striae fine, shallow, simple with moderate punctures.

Legs. Fore tibiae slightly elongate with an apical brush of setae. Otherwise unmodified.

Abdomen. Pygidium smooth, nitid, slightly convex, scattered punctures with short recumbent setae except on centre one-third. Aedeagus as in Fig. 55.
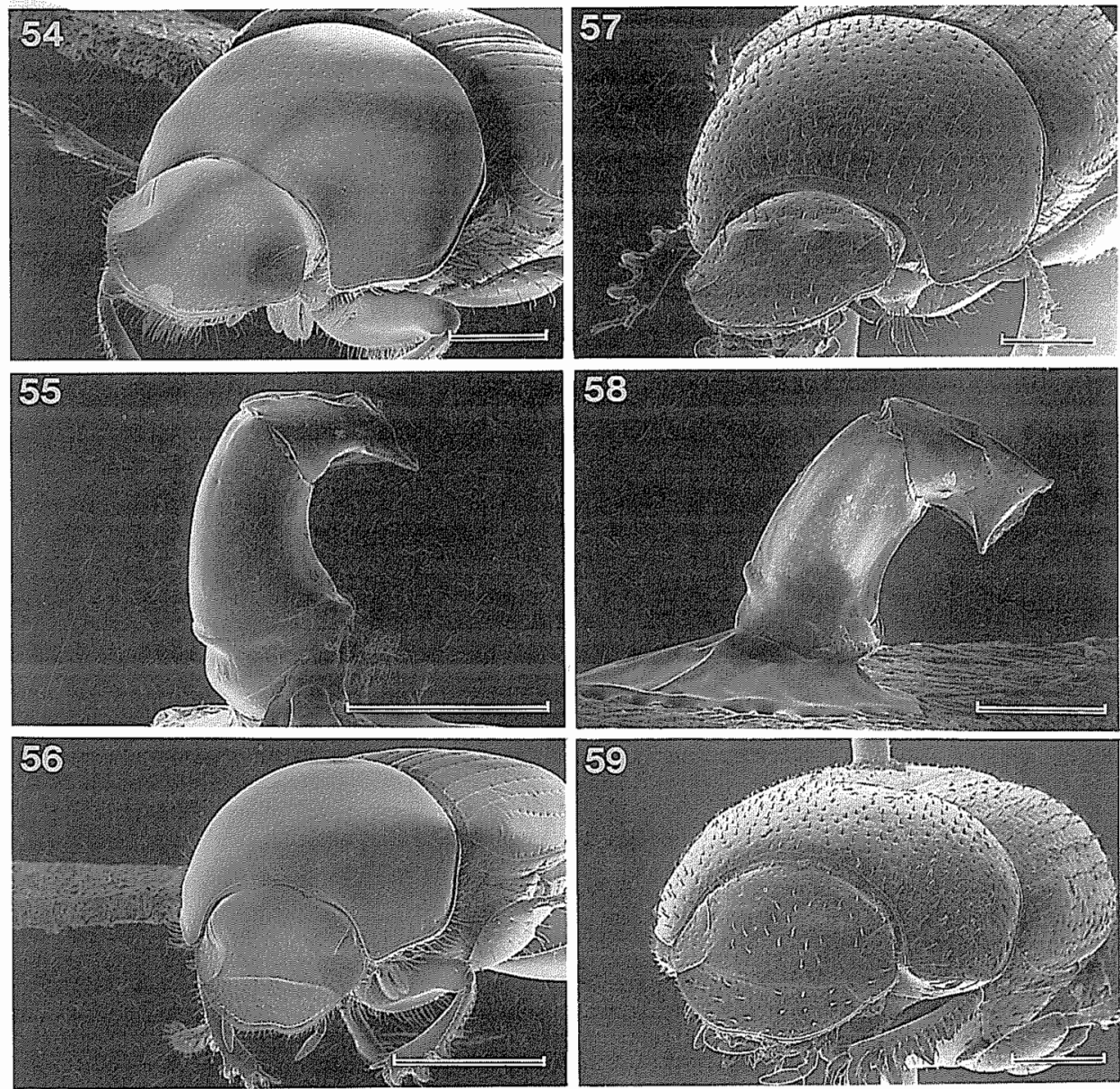

Figs 54-56. Onthophagus trawalla: 54, head and pronotum, male; 55, aedeagus; 56, head and pronotum, female.

Figs 57-59. Onthophagus mije: 57 , head and pronotum, male; 58, aedeagus; 59, head and pronotum, female.

Scale lines: $56,1 \cdot 0 \mathrm{~mm} ; 54,55,57,59,0.5 \mathrm{~mm} ; 58,0.25 \mathrm{~mm}$. 


\section{Female}

Clypeus punctate, feebly rugose, clypeal suture complete, in form of a ridge across head joining genal sections near margin. Eyes slightly wider. Fore tibiae unmodified. Otherwise like male.

\section{Distribution (Fig. 5)}

Known only from the Iron Range area of Cape York Peninsula; trapped with human excrement baits in closed forest.

\section{Comments}

This species runs to $O$. wilgi Matthews in Storey's (1977) key. It differs from that species in the anterior half of the lateral margin of the pronotum being less rounded, the shape of the male aedeagus, and in distribution.

\section{bicarinaticeps group}

Onthophagus mije, sp. nov.

(Figs 57-59)

\section{Material Examined}

Holotype. ơ, Queensland: 'Mourangee', Edungalba, 28-29.iii.1975, R. I. Storey and E. Adams, in QM, T10 892.

Paratypes. (80), Queensland: $130^{\circ}, 6 \%$, same data as holotype, $1 \%$, same locality as holotype, 4.i.1975, E. E. Adams; 10 ' 1 \%, $3 \mathrm{~km} \mathrm{~N}$. of 'Mourangee', 4.i.1975, E. E. Adams; 1 o (Paratype of O. yeyeko Matthews), Finch Hatton Cr, 27.iii.1968, E. Matthews; 20*, 1९, Forty Mile Scrub, $66 \mathrm{~km}$ W. of Mt Garnet, 31.v.1972, G. B. Monteith; 10, 1९, same data, 26.v.1975, R. I. Storey; 100, 16o, same data, 14-15.ii.1976, 120, 12 , same data, 20-21.xi.1976, 1o, same data, 23.xii.1977; $10^{\circ}, 15^{\circ} 16^{\prime} \mathrm{S} ., 144^{\circ} 59^{\prime}$ E., $14 \mathrm{~km} \mathrm{~W}$. by N. of Hopevale Mission, 7-10.v.1981, J. Feehan. Paratypes in: ANIC, QDPIM, QM, QUE.

\section{Description}

Rufopiceus to black with clypeal margin, anterior angles of pronotum, apices and humeri of elytra, legs, abdominal sternites and pygidium sometimes paler, antennal clubs fuscous almost black. Total length $3 \cdot 0-3 \cdot 8 \mathrm{~mm}$.

\section{Male}

Head. Clypeal margin medially shallowly emarginate, lateral margins almost straight to genal angles which are rounded. Frontal section of clypeal suture effaced, genal sections very finely beaded. Frons with a pair of low transverse ridges, one near each eye, slightly angled forward, feebly carinate; ridges less developed in minor male. Eyes dorsally 6-7 facet rows in width, separated by $9-10$ eye widths, canthus incomplete. Surface of head smooth, nitid, with medium and large punctures scattered irregularly over the surface, the large ones each with a short erect seta. Labium emarginate.

Pronotum. Convex, unsculptured. Anterior angles quadrate, apices rounded. Hind edge finely margined. Surface smooth, nitid, with numerous medium punctures at regular intervals, separated by about one diameter, each with a short erect seta, the apical half of which is recurved backwards towards surface, almost touching, also a few finer punctures without setae.

Elytra. Intervals flat to feebly convex, smooth, nitid, with one or two rows of medium punctures, each with a recurved seta as on pronotum, more on last interval. Striae impressed, geminate, with moderate punctures.

Legs. Apical edge of fore tibiae quadrate.

Abdomen. Pygidium convex, smooth, nitid, scattered moderate punctures each with a seta as in pronotum except along midline which has fine punctures without setae. Aedeagus as in Fig. 58. 


\section{Female}

Head with clypeal suture carinate, arcuate; transverse ridges on frons not carinate, swellings only. Pronotum less convex. Pygidium less convex. Apical edge of fore tibiae oblique. Otherwise like male.

\section{Distribution (Fig. 5)}

This species is known from central Queensland to Cooktown in dense scrub on volcanic soil in relatively dry situations. Trapped with human excrement baits and collected in wallaby dung.

\section{Comments}

This species is closely relate to $O$. lamgalio Matthews and $O$. yeyeko Matthews but can be separated from them by the longer and much more recurved setae on the pronotum and elytra. The male of $O$. mije has the frontal section of the clypeal suture completely effaced and a pair of low transverse ridges on the frons while the males of both $O$. lamgalio and $O$. yeyeko have the frontal section of the clypeal suture well developed and carinate and lack any ridges on the frons. The female of $O$. mije has a pair of transverse swellings on the frons whereas females of the other two species have a completely unsculptured frons as in the males.

\section{Ungrouped Species}

\section{Onthophagus binyana, sp. nov.}

\section{Material Examined}

$$
\text { (Figs 60-63) }
$$

Holotype. O*, Queensland: Kuranda St. Forest, $360 \mathrm{~m}, 3 \mathrm{~km} \mathrm{~N}$. of Kuranda, 25.vi-3.viii.1982, S. and J. Peck, in ANIC, ANIC No. 100.

Paratypes. (43), Queensland: $2 \circ^{\circ}, 2 \wp$, same data as holotype; $2 \wp$, Kirrama Range, via Kennedy, 8.v.1974, R. I. Storey; $10^{\circ}$, Laceys Creek, $40 \mathrm{~m}, 10 \mathrm{~km} \mathrm{SE}$. of El Arish, 23.vi-5.viii.1982, S. and J. Peck; 4०*, 4q, Bellenden Ker Range, Cableway Base Stn, 100 m, 17.x-9.xi.1981, Earthwatch/
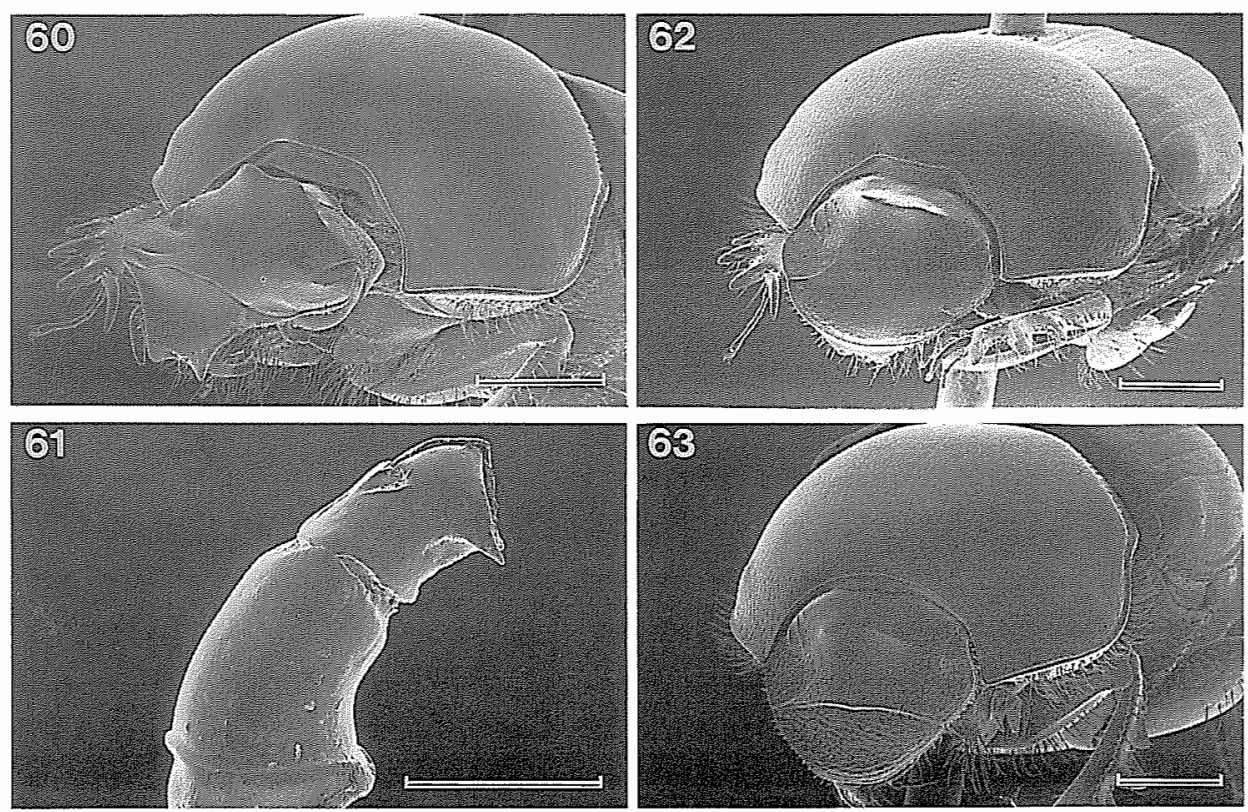

Figs 60-63. Onthophagus binyana: 60, head and pronotum, major male; 61, aedeagus; 62, head and pronotum, minor male; 63 , head and pronotum, female.

Scale lines: $60,62,63,1.0 \mathrm{~mm} ; 61,0.5 \mathrm{~mm}$. 
Qld Museum; 10, Bellenden Ker Range, 0.5 km S. of Cable Tower No. 7, 500 m, 25-31.x.1981, Earthwatch/Qld Museum; $1 \sigma$, 4 km NNW. of Kuranda, 10.xii.1984-15.i.1985, Storey and Halfpapp; $1 \sigma^{\circ}$, same data, 1.v-14.vi.1985; $1 \%, 2 \wp, 7 \cdot 5 \mathrm{~km}$ NNW. of Kuranda, 15.i-20.ii.1985, Storey and Halfpapp; $1 \sigma, 1 \%$, same data, 20.ii-20.iii.1985, 1o , same data, 20.iii-1.v.1985, Storey and Titmarsh; 1ᄋ, Danbulla S.F., $13 \mathrm{~km} \mathrm{NE}$. of Yungaburra, 13.ii-6.iii.1987, Storey and De Faveri; $1 \%, 1 \%$, same data, 6-26.iii.1987; $1 \sigma$, Mt Lewis, $900 \mathrm{~m}, 20 \mathrm{~km}$ SW. of Mossman, 26.vi-1.viii.1982, S. and J. Peck; 3o , $11 \mathrm{~km}$ up Mt Lewis Rd, 26.xii.1986-8.i.1987, Howden and Storey; 2ф, Windsor Tableland, $38 \mathrm{~km}$ from main road, 20.xii.1985-15.i.1986, Storey and Brown; $1 \sigma^{\circ}$, Windsor Tableland, $46 \mathrm{~km}$ from main road, 15.i-5.iii.1986, Storey and Brown; $1 \sigma^{\circ}$, same data, 5.iii-8.v.1986; 4o, $1 \%$, Bloomfield Rd, via Helenvale, 20-27.vii.1974, G. Monteith and D. Cook; 1o, same data, 21-22.v. 1975, D. L. Hancock; 1\%, same data, 24.xii.1979, R. I. Storey; 1\%, 15 $47^{\prime}$ S., $145^{\circ} 17^{\prime}$ E., Moses Ck, $4 \mathrm{~km} \mathrm{~N}$. by E. of Mt Finnigan, 14-16.x.1980, T. Weir. Paratypes in: ANIC, HFHC, QDPIM, QM, QUE.

\section{Description}

Black, forebody with a faint green or bronze tinge, antennal clubs fulvous. Total length $5 \cdot 1-7 \cdot 5 \mathrm{~mm}$.

\section{Male}

Head. Clypeal margin expanded into a downward facing lobe, the face of this lobe at right angles to plane of dorsal portion of frontoclypeus, and in length about half distance to base of head. The lower margin of this lobe is bifurcate, rounded between, and lateral margins slightly concave to the rest of the clypeal margin. The dorsal margin is feebly emarginate, raised slightly above plane of frontoclypeus. Rest of clypeal margin convex to genal angles which are subquadrate, rounded. Clypeal suture with frontal section effaced. Vertex with a broad lamina, about midway between front of eyes and back of head, as high as wide, the apex feebly sinuate and about one-third of the distance between eyes in width, lateral margins at about $45^{\circ}$ to plane of head. Modifications to clypeal margin reduced in minor male towards condition of female. Eyes narrow dorsally, about six facet rows in width, separated by about 12 eye widths, canthus incomplete. Surface of clypeal lobe
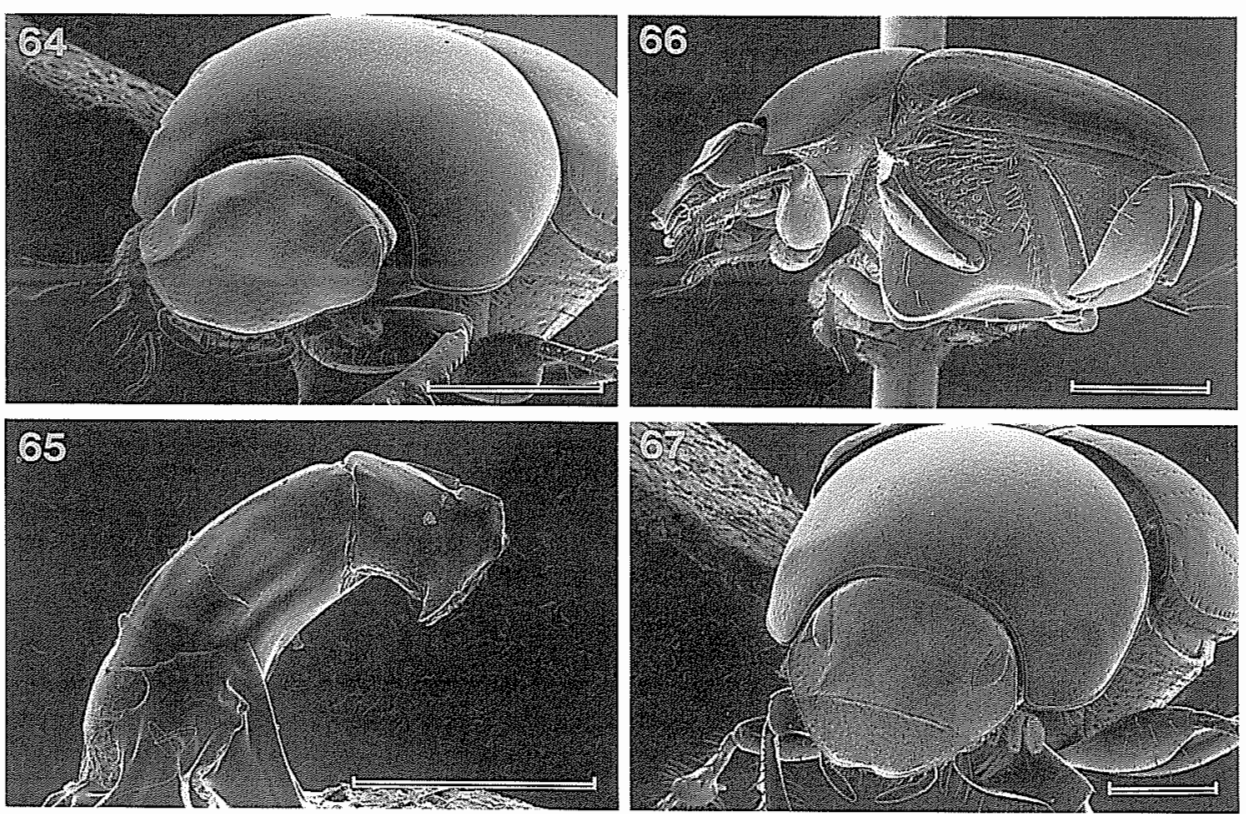

Figs 64-67. Onthophagus bundara: 64, head and pronotum, male; 65, aedeagus; 66, whole body, lateral, major male; 67 , head and pronotum, female.

Scale lines: $64,66,1.0 \mathrm{~mm} ; 65,67,0.5 \mathrm{~mm}$. 
impunctate, smooth, nitid, surface of head impunctate except some moderate punctures around eyes and basal angles of clypeus, smooth, nitid.

Pronotum. Strongly convex, anterior face feebly protruding, rest of surface unsculptured. Anterior angles subquadrate. Middle section of frontal margin with a shallow, broad emargination. Hind margin with a narrow flattened area in front, widest at basal angles, this depression with fine parallel carinae at regular intervals. Surface moderately punctate with medium punctures separated by 1-3 diameters, finer and more scattered on centre of disc.

Elytra. Intervals flat with very fine punctures, surface smooth, shagreened, glabrous. Striae fine, nitid, with fine punctures.

Legs. Fore tibiae slightly elongate.

Abdomen. Pygidium slightly convex, shagreened, moderately punctate with moderate punctures, with short recumbent setae near basal angles. Aedeagus as in Fig. 61.

\section{Female}

Clypeal margin rounded, unmodified; apex a bit flattened, frontal section of clypeal suture carinate, clypeal surface strongly transversely rugose. Frons with a low, fine, sinuate carina about half distance between eyes in width, surface moderately punctate with fine punctures, less so behind carina, and strongest around eyes. Pronotum less convex, front margin without a broad emargination, more nitid. Elytra more or less nitid. Fore tibiae unmodified. Otherwise like male.

\section{Distribution (Fig. 5)}

Although never common, with no specimens being taken before 1974, this unusual species is really quite widespread on the Great Dividing Range and adjacent areas from Kirrama to just north of Bloomfield River, from near sea level to at least $900 \mathrm{~m}$. Trapped with human excrement baits and taken in flight intercept/trough traps.

\section{Comments}

This species is closely related to $O$. bunamin Matthews, to which it runs in Matthews' (1972) key. It shares with that species the same stocky build (especially in the male), the strongly elevated frontal carina in the male, and the unusual finely carinate flat areas near the basal pronotal margin. $O$. binyana can be separated from $O$. bunamin by the frontal carina being narrower in both sexes and by the lack of distinct red areas on the humeri and sides of elytra. The downturned clypeal lobe, which sits in front of the mouthparts of the major male of $O$. binyana, is unique in Australian Onthophagus.

\section{Acknowledgments}

We wish to thank the curators of the various collections listed for the loan of specimens and $\mathrm{Mr} \mathrm{C}$. Beaton, Mr E. Hines and Ms K. Pickerd of the Electron Microscopy Unit, CSIRO Division of Entomology, Canberra for Figs 6-67.

\section{References}

Matthews, E. G. (1972). A revision of the scarabaeine dung beetles of Australia. 1. Tribe Onthophagini. Australian Journal of Zoology, Supplement 9, 1-330.

Reed, A. H., and Reed, A. W. (1965). 'Aboriginal Words of Australia.' (A.H. and A.W. Reed: Sydney.)

Storey, R. I. (1977). Six new species of Onthophagus Latreille (Coleoptera: Scarabaeidae) from Australia. Journal of the Australian Entomology Society 16, 313-20. 